\title{
Dual Role of the PTPN13 Tyrosine Phosphatase in Cancer
}

\author{
Soha Mcheik ${ }^{1, \dagger}{ }^{\dagger}$ Leticia Aptecar ${ }^{1, t}+$, Peter Coopman ${ }^{1,2} \mathbb{D}$, Véronique $D^{\prime}$ Hondt $^{1}$ and \\ Gilles Freiss $1, * \mathbb{D}$ \\ 1 IRCM, Institut de Recherche en Cancérologie de Montpellier, INSERM U1194, Université de Montpellier, \\ Institut régional du Cancer de Montpellier, F-34298 Montpellier, France; soha.mcheik@inserm.fr (S.M.); \\ 1.aptecar@hotmail.fr (L.A.); peter.coopman@inserm.fr (P.C.); Veronique.Dhondt@icm.unicancer.fr (V.D.) \\ 2 CNRS-Centre National de la Recherche Scientifique, 1919 Route de Mende, 34293 Montpellier, France \\ * Correspondence: gilles.freiss@inserm.fr; Tel.: +33-(0)4-67-61-24-33 \\ + These authors contributed equally to this work. \\ $\ddagger$ Present address: CHU Saint Eloi, Montpellier, Service Oncologie Médicale, 80 Avenue Augustin Fliche, \\ 34090 Montpellier, France.
}

Received: 16 November 2020; Accepted: 9 December 2020; Published: 11 December 2020

\begin{abstract}
In this review article, we present the current knowledge on PTPN13, a class I non-receptor protein tyrosine phosphatase identified in 1994. We focus particularly on its role in cancer, where PTPN13 acts as an oncogenic protein and also a tumor suppressor. To try to understand these apparent contradictory functions, we discuss PTPN13 implication in the FAS and oncogenic tyrosine kinase signaling pathways and in the associated biological activities, as well as its post-transcriptional and epigenetic regulation. Then, we describe PTPN13 clinical significance as a prognostic marker in different cancer types and its impact on anti-cancer treatment sensitivity. Finally, we present future research axes following recent findings on its role in cell junction regulation that implicate PTPN13 in cell death and cell migration, two major hallmarks of tumor formation and progression.
\end{abstract}

Keywords: PTPN13; cell signaling; cancer; tumor suppressor; oncogene

\section{Introduction}

Tyrosine phosphorylation is a key post-translational modification and a major research topic because of its crucial role in the control of cell proliferation, cycle progression, differentiation, and development. The interest in protein tyrosine phosphatases has been growing steadily in the last 25 years.

In this review, we focus on protein tyrosine phosphatase non-receptor 13 (PTPN13) because many studies have highlighted its possible dual role in cancer. PTPN13 was first named PTP-BAS [1], hPTP1E [2], and PTP-L1 [3] since it was cloned by three different groups, then renamed FAS-associated phosphatase 1 (FAP-1) by Sato et al because of its interaction with Fas [4]. PTPN13 belongs to the Class I superfamily of tyrosine-specific phosphatases in which the catalytic domain contains a cysteine residue [5]. Substitution of this cysteine residue by a serine results in a catalytically inactive form (PTPN13-C/S) [6]. PTPN13 is a soluble and cytosolic non-receptor protein that can be translocated to the sub-membranous and nuclear compartments [7] during mitosis [8]. The PTPN13 gene is located on chromosome 4q21.3 and encodes the non-receptor protein phosphatase with the highest molecular weight (270 kDa; 2466 amino acids) [9].

PTPN13 is composed of an N-terminal KIND domain of unknown function, followed by a FERM domain and five PDZ domains before the catalytic phosphatase domain located at the C terminus [1] (Figure 1). The FERM domain is common to the family of membrane proteins that link the cytoskeleton 
to the plasma membrane [10]. The FERM domain of PTP-BL (PTPN13 murine ortholog with 80\% of homology [11]) is sufficient to support its sub-membranous localization [12]. We showed that PTPN13 is mainly localized at the plasma membrane in HeLa cells, and that the FERM domain is necessary and sufficient to direct the enzyme to the membrane [13]. Kimber et al. showed that tandem pleckstrin homology-domain-containing protein (TAPP1), which binds PtdIns(3,4)P2 and the first PDZ domain of PTPN13, participates in the regulation of its membrane localization [14]. Moreover, the FERM domain allows the interaction of PTPN13 with other proteins, such as serologically defined colon cancer antigen 3/endosome-associated trafficking regulator 1 (SDCCAG3/ENTR1) that is overexpressed in colon cancer and is involved in cytokinesis regulation [15]. PDZ domains are protein interaction domains that are used as scaffolding platforms in protein complexes, mostly associated with the plasma membrane [16]. Multiple partners of PTPN13 PDZ domains have been identified [17] and they are often involved in carcinogenesis and/or in cytoskeleton organization and cell migration (Figure 1; Table 1).

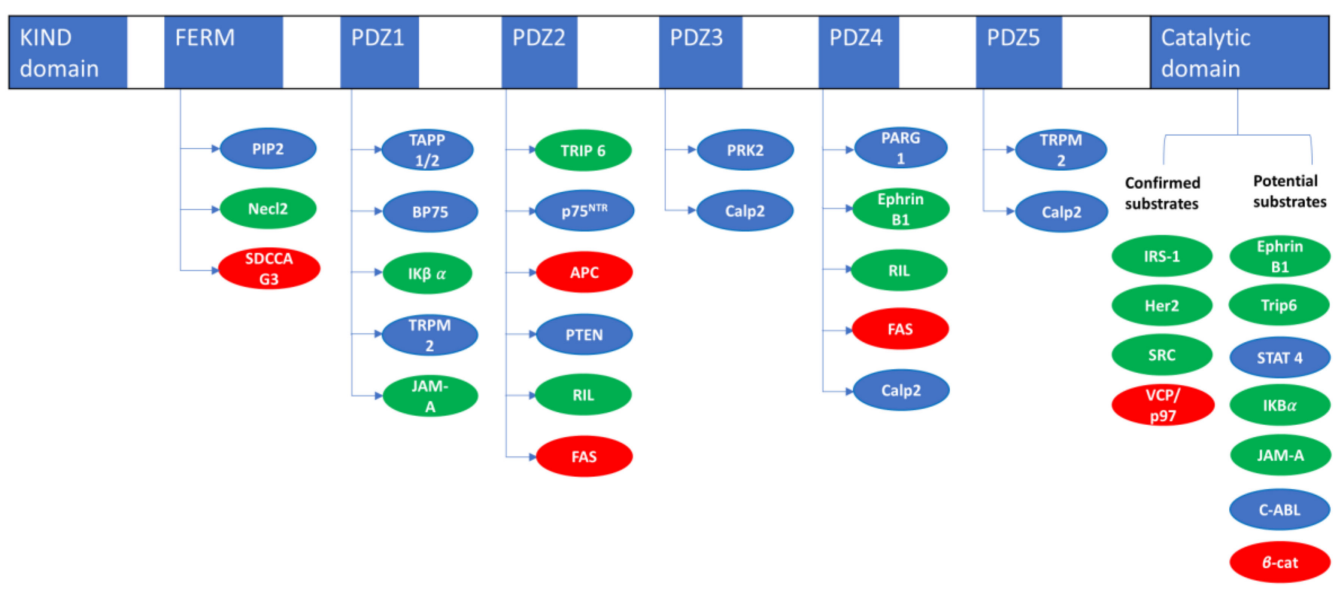

Figure 1. PTPN13 structure, interactions, and substrates. Interactors or substrates in green were involved in PTPN13 tumor suppressor role. Interactors or substrates in red were involved in PTPN13 pro-tumoral role. KIND domain: kinase non-catalytic C-lobe domain (unknow function), FERM: 4.1/Ezrin/radixin/moesin domain (protein/protein and protein/plasma membrane interaction), PDZ domains: PSD95/Dlg1/Zo-1 domain (protein/protein interaction domain), Calp2: Calpain-2, $\beta$-cat: $\beta$-catenin.

Table 1. PTPN13 interacting proteins.

\begin{tabular}{ccc}
\hline \multicolumn{3}{c}{ PTPN13 Interacting Proteins } \\
\hline Name & Interacting Domain & Reference \\
\hline Nec12 & FERM & {$[18]$} \\
\hline SDCCAG3/ENTR1 & FERM & {$[15]$} \\
\hline TAPP 1/2 & PDZ1 & {$[14]$} \\
\hline BP75 & PDZ1 & {$[19]$} \\
\hline IkB $\alpha$ & PDZ1 & {$[20]$} \\
\hline TRPM2 & PDZ15 & {$[21]$} \\
\hline JAM-A & PDZ-1 & {$[22]$} \\
\hline TRIP6/ZRP1 & PDZ2 & {$[23]$} \\
\hline P75 ${ }^{N T R}$ & PDZ2 & {$[24]$} \\
\hline APC & PDZ2 & {$[25]$} \\
\hline RIL & PDZ2-4 & {$[26]$} \\
\hline FAS & PDZ2-4 & {$[27]$} \\
\hline PTEN & PDZ2 & {$[28]$} \\
\hline PRK2 & PDZ3 & {$[29]$} \\
\hline Calp2 & PDZ3-4-5 & {$[30]$} \\
\hline PARG1 & PDZ4 & {$[31]$} \\
\hline EphrinB1 & PDZ4 & {$[32]$} \\
\hline & &
\end{tabular}


Little is known about PTPN13 physiological role. Ptpn13 gene ablation does not induce major changes in mice. Its loss in murine CD4 T cells increases their differentiation into Th1 and Th2 helper T lymphocytes and enhances the immune defenses against Klebsiella pneumoniae [33]. Moreover, PTP-BL plays a role in adipocyte differentiation [34], and loss of its catalytic activity slightly affects motor neuron repair in mice [35]. In this review, we mainly describe its implication in cancer-related signaling pathways and biological processes (Figure 2, Table 2).

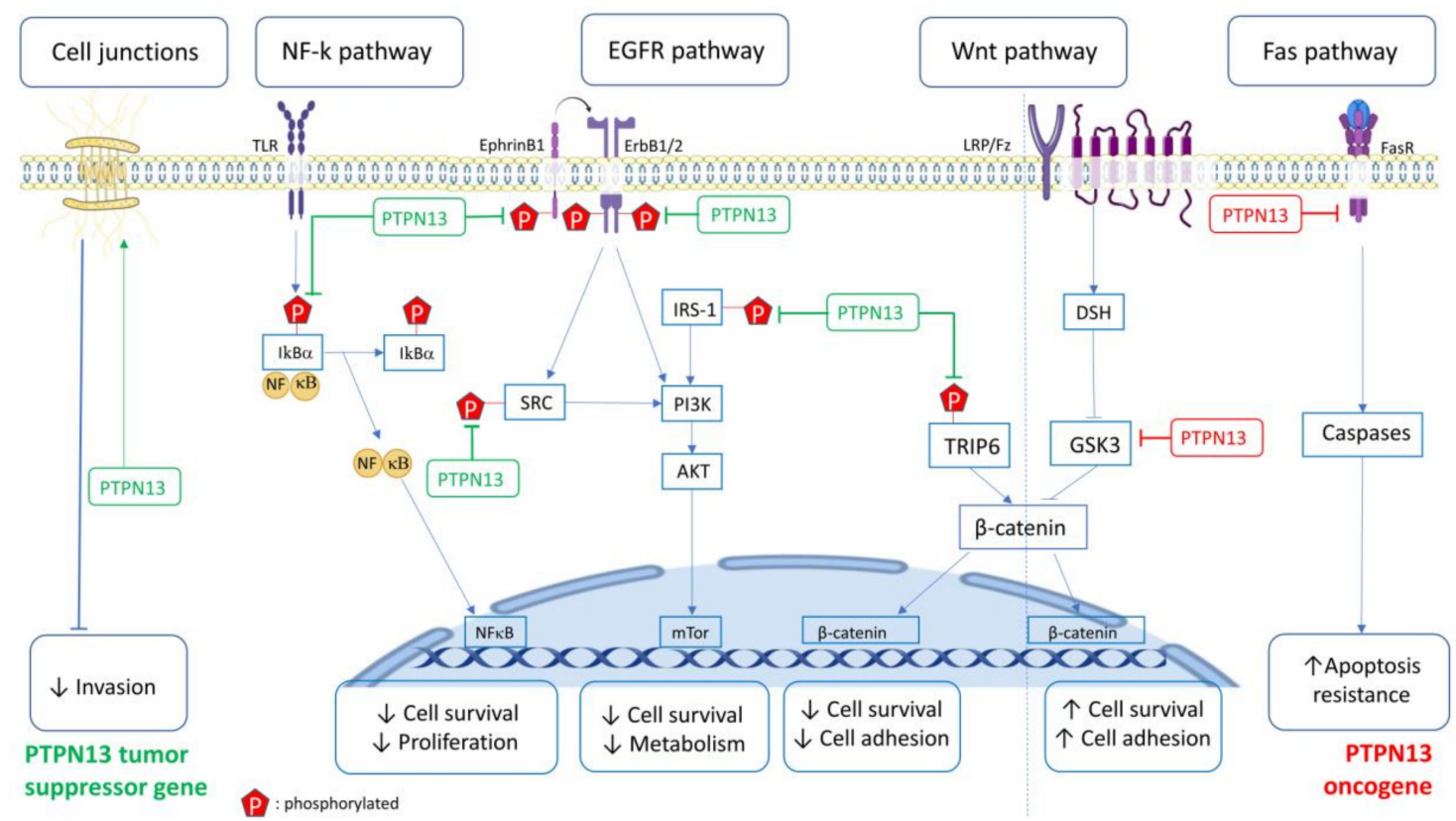

Figure 2. PTPN13 is involved in multiple signaling pathways. PTPN13 in green: Tumor suppressor role; PTPN13 in red: Pro-tumoral role. Arrow pointing to P: PTPN13 effects mediated by its phosphatase activity. TLR: Toll-like receptor, LRP/Fz: lipoprotein receptor-related protein/Frizzled.

Table 2. PTPN13 Susbstrates.

\begin{tabular}{cccc}
\hline \multicolumn{4}{c}{ PTPN13 Substrates Evidences } \\
\hline Name & Dephosphorylation & Substrate Trapping & Reference \\
\hline IRS1 & In vitro/in cellulo & In vitro/in cellulo & {$[36]$} \\
\hline HER2 & In cellulo & In cellulo & {$[37]$} \\
\hline SRC & In vitro/in cellulo & In vitro/in cellulo & {$[38]$} \\
\hline VCP/P97 & In vitro/in cellulo & In vitro/in cellulo & {$[39]$} \\
\hline EphrinB1 & In vitro/in cellulo & & {$[40]$} \\
\hline Trip6 & In vitro/in cellulo & & {$[41]$} \\
\hline STAT 4 & In vitro/in cellulo & & {$[33]$} \\
\hline IкB $\alpha$ & In vitro/in cellulo & & {$[42]$} \\
\hline JAM-A & In vitro & & {$[22]$} \\
\hline C-ABL & In cellulo & & {$[30]$} \\
\hline$\beta$-catenin & In cellulo & & \\
\hline
\end{tabular}




\section{Signaling Pathways and Biological Activities Affected by PTPN13}

\subsection{FAS Pathway}

PTPN13 role in FAS-mediated apoptosis has been extensively studied. The first reported evidence was the interaction of PTPN13 with the FAS (CD95/APO-1) death receptor. Many cancer cell lines develop resistance to FAS-induced apoptosis by acquiring mutations in the FAS gene [44] or by regulating FAS availability at the cell surface [45]. It has been demonstrated that PTPN13 reduces FAS cell surface level, and that the second and fourth PDZ domain of PTPN13 directly interact with FAS C-terminus [27,46,47]. Moreover, blocking this PDZ domain with a serine/leucine/valine (SLV) tripeptide, which represents the FAS C-terminus sequence required for the association with PTPN13, prevents the interaction of PTPN13 with partner proteins, leading to restoration of FAS-induced apoptosis [47-51]. In agreement with these findings, Gagnoux-Palacios L et al. showed that FAS interacts via its SLV terminal sequence with PDZ domain-containing proteins associated with cell junctions [52], such as the scaffolding protein Discs Large homolog 1 (DLG1) and PTPN13 that is involved in cell junction stabilization in breast cancer [53]. They then demonstrated that adherens junctions (AJs) play a role in tissue homeostasis by sequestering FAS and inhibiting apoptosis. AJ disruption allows the release of FAS and increases the number of cells sensitive to FasL-mediated cell death [52]. They also established that transfection of HCT15 cells with siRNAs against DLG1 increases FAS-induced cell death. As this effect is correlated with an increase in total and cell surface FAS expression, DLG1 might inhibit FAS cell death by impairing Death Inducing Signaling Complex (DISC) formation [52].

Using siRNA-mediated knockdown or overexpression, Ivanov et al. demonstrated PTPN13 implication in FAS localization. Specifically, forced expression of PTPN13 in FEMX melanoma and HeLa cervical carcinoma cells leads to reduced surface and higher intracellular expression of FAS. Conversely, FAS surface expression is upregulated after transfection of TIG3 bladder carcinoma cells with PTPN13 dominant negative mutants or after PTPN13 silencing by siRNA [45]. In line with these findings, PTPN13 overexpression in Capan-1 pancreatic carcinoma cells negatively regulate FAS-mediated apoptosis [54], and PTPN13 silencing by siRNA in SW480 colorectal cancer cells increases FAS/FasL-mediated apoptosis [55]. Consistent with these results, another study reported that the microRNA mir-200c sensitizes cells to FAS-induced apoptosis by targeting PTPN13 [56].

Erdmann's group proposed a mechanism whereby PTPN13 regulates FAS membrane trafficking. First, they showed that in HeLa cells, PTPN13 can bind to ENTR1 (an endosome-associated trafficking regulator that controls sensitivity to tumor necrosis factor-induced apoptosis [57], also known as SDCCAG3) and that these two partners play a role in cytokinesis [15]. Then, they confirmed that ENTR1 negatively regulates FAS surface expression and FAS-induced apoptosis by participating in FAS endolysosomal sorting [58]. In addition, they reported that the regulation of FAS surface expression requires the interaction between PTPN13 and ENTR1, and the colocalization of FAS, ENTR1, and PTPN13 in early endosomes [58].

Eklund's group showed that in myeloid progenitor cells, BCR/ABL activation leads to PTPN13 upregulation and inhibition of FAS-induced apoptosis. This inhibitory effect is abolished by the SLV peptide [59], suggesting PTPN13 involvement. Interestingly, another study reported that PTPN13 can dephosphorylate and inhibit c-Abl[30], suggesting a possible retro-control of ABL activity that is lost in the case of the BCR/ABL translocation. Then, Eklund's group demonstrated that in $\mathrm{BCR} / \mathrm{ABL}$-overexpressing myeloid progenitor cells, PTPN13 interacts with adenomatous polyposis coli (APC), and that this interaction, which involves the same PDZ domain, is inhibited by the SLV peptide [60]. BCR/ABL overexpression leads to a decrease in tyrosine phosphorylation of GSK3 $\beta$ (an APC partner) and in serine phosphorylation of $\beta$-catenin (a GSK3 substrate), and consequently to increased $\beta$-catenin transcriptional activity [60]. All these BCR/ABL-mediated effects can be reversed by the SLV peptide, suggesting PTPN13 implication. Using a murine model of chronic myeloid leukemia (CML) stem cells transplantation, Eklund's group reported that administration of 
the SLV peptide (to inhibit PTPN13), in addition to the standard treatment with the BCR/ABL inhibitor imatinib, delays tumor development, suggesting an inhibition of leukemia stem cell persistence [61]. More recently, they showed that increased PTPN13 expression characterizes CD133+ colon cancer stem cells and that PTPN13 upregulation in metastases, compared with primary tumors or after platinum-based chemotherapy, is due to the relative abundance of these cancer stem cells in the tumor [51].

In line with these results, Sardina et al. observed increased PTPN13 expression during megakaryocytic differentiation. This inhibits differentiation and limits tyrosine and serine phosphorylation of $\beta$-catenin, leading to higher transcriptional activity [43]. In this model, PTPN13 overexpression is induced by the Wnt pathway that stabilizes PTPN13, and the PTPN13- $\beta$-catenin interaction appears to be direct [43].

On the other hand, Castilla et al. found that PTPN13 plays a pro-apoptotic role in PC3 and LNCaP prostate adenocarcinoma cells. Specifically, its overexpression enhances apoptosis in cells incubated with phenylethyl isothiocyanate and anti-FAS antibodies or with paclitaxel [43]. Conversely, PTPN13 downregulation leads to resistance to apoptosis upon exposure to these agents [62]. Furthermore, they showed that PKC $\delta$ acts as an intermediary in PTPN13-mediated apoptotic signaling, and that inhibition of $\mathrm{I} \kappa \mathrm{B} \alpha$ degradation and suppression of NF- $\kappa \mathrm{B}$ activity by $\mathrm{I} \kappa \mathrm{B} \alpha$ association and dephosphorylation are partly regulated by PTPN13 and PKC $\delta$. Finally, they reported that PTPN13 and PKC $\delta$ expression are lost in poorly differentiated, more aggressive human prostate cancer specimens, suggesting a correlation between their absence, apoptosis resistance and tumor progression [62].

In the pancreatic adenocarcinoma A818-6 cell line, anti-FAS antibodies induce apoptosis in cells grown in 2D- or 3D-polarized cell cultures, independently of PTPN13 and FAS colocalization [63]. Moreover, inhibition of PTPN13 expression does not affect apoptosis induced by anti-FAS agonistic antibodies, suggesting that PTPN13 is not involved in the regulation of FAS-induced apoptosis in this cell type [63].

In conclusion, PTPN13 inhibitory role in FAS-induced apoptosis is well documented in the hematopoietic system. Conversely, its role in solid tumors is less clear due to the multiple signaling pathways regulated by PTPN13, and particularly due to its role in cell junction maintenance that contributes to FAS-induced apoptosis regulation.

\subsection{SRC, Ephrin, ErbB Pathways}

$\mathrm{SRC}$ is a non-receptor pro-oncogenic tyrosine kinase that participates in different pathways, for instance, the integrin [64], EGFR [65], and ephrin signaling cascades [40,66].

SRC [38], ephrinB [40], EGFR [67], and HER2 [37,38] signaling are inhibited by PTPN13 that limits anchorage-independent cell growth (SRC) [49], cell proliferation (HER2 and EGFR) [67], and also invasion and tumor aggressiveness (SRC, HER2) [37,38].

Several PTPN13 partners involved in these inhibitory effects have been identified. For instance, in HCT116 colon cancer cells, PTPN13 inactivates SRC through interaction with reversion-induced LIM domain protein (RIL) [68], and in A549 pulmonary and Caco-2 colon adenocarcinoma cells, it inhibits the ERBB3/ERBB2 receptors through association with nectin-like molecule 2 (NECL2) [18]. In addition, there may be a HER2-induced feedback mechanism that induces the expression of PTPN13 and thereby negatively regulates its own signaling pathways [69].

In 2012, Vermeer et al. discovered a new signaling pathway that involves ephrinB1, ERBB2, and ERK and that is regulated by PTPN13 in breast cancer cell lines [70]. Specifically, PTPN13 silencing by shRNA leads to ERBB2 overexpression and to phosphorylation of ephrinB1 (a PTPN13 substrate) that forms a complex with ERBB2 and induces ERK1/2 phosphorylation in breast cancer (MDA-MB-468), human keratinocyte (HaCaT) and head and neck squamous cancer (UM-SCC84) cell lines. Formation of the ephrinB1/ERBB2 complex was confirmed by coimmunoprecipitation experiments and by their colocalization at intercellular junctions. Moreover, ephrinB1/ERBB2 complex formation is promoted by expression of a constitutively active oncogenic mutant of ERBB2. Signaling by this complex is activated 
by SRC and is increased by transfection of the catalytically inactive PTPN13-C/S variant. These findings were also confirmed by proximity ligation assay and ephrinB1/ERBB2 coimmunoprecipitation in head and neck cancer cell lines [71]. Besides ERBB2, ephrinB1 interacts with ERBB1 that is overexpressed in head and neck cancer [72]. This interaction, which is promoted by human papilloma virus 16 (HPV16) (known to inhibit PTPN13 in this cancer type [73]), activates the MAPK pathway [70]. Transfection of HEK293 cells with the PTPN13-C/S mutant increases ephrinB1 phosphorylation, its association with ERBB1, and ERK1/2 phosphorylation. These effects are not observed upon transfection of wild-type PTPN13 [71]. Altogether, these data indicate that PTPN13 regulates phosphorylation of ephrinB1, which preferentially associates with ERBB1 in head and neck cancer, and allows MAPK pathway activation.

In vivo, in a mouse model of HPV-positive head and neck squamous cancer (HNSCC), tumor growth was reduced $(p<0.001)$ and survival was improved $(p<0.001)$ in mice injected with HNSCC cells transfected with ephrinB1 shRNA compared with cells transfected wild-type ephrinB1 [71]. This suggests that ephrinB1 may have a pro-oncogenic role through activation of the MAPK pathway via the ephrinB1/ERBB2 [70] or ephrinB1/ERBB1 complexes [71].

Other studies on PTPN13 regulation using miRNAs support these results, notably in bronchial adenocarcinoma [74,75] and esophageal carcinoma [76] cell lines. Moreover, NECL2 and NECL4 can interact with PTPN13 to inhibit the ERBB2/ERBB3 pathway in colorectal cancer (Caco-2), breast cancer (MCF7), and human embryonic kidney (HEK293) cells [77,78].

In conclusion, the ephrinB1/ERBB2 (in breast cancer) and ephrinB1/ERBB1 (in head and neck cancer) complexes induce MAPK pathway activation and are positively regulated by SRC and negatively regulated by PTPN13.

\subsection{PTPN13 Is Implicated in HPV16 Carcinogenicity}

The HPV proteins E6 and E7 exert their oncogenic activity through inhibition of the p53 and pRb tumor suppressor genes, respectively [79,80]. In addition, E6 binds to several PDZ domain-containing proteins, including PTPN13, via a PDZ binding domain (PBM), leading to their proteasome-mediated degradation [81,82]. By transfecting wild-type and PBM-mutated E6 proteins in human and mouse keratinocytes, Spanos' group confirmed that HPV16-induced degradation of PTPN13 promotes anchorage-independent tumor cell proliferation [59]. In vivo, expression of an activated RAS mutant enhances the growth of epithelial cells (MTECs) transfected with wild-type E6 [83]. This RAS effect is not observed when cells are co-transfected with PTPN13 shRNA or PBM-mutated E6, suggesting that RAS activation acts in conjunction with PTPN13 inhibition to promote tumor proliferation.

More recently, Wieking et al. showed that HPV inhibition of PTPN13 and p53 is involved also in the induction of epithelial mesenchymal transition (EMT). Indeed, infection of human tonsillar epithelial cells with a non-oncogenic mutated HPV16 virus (unable to degrade p53, pRb, PTPN13, or to activate telomerases) did not induce EMT, unlike transfection with wild-type HPV16 [84].

Thus, E6-mediated inhibition of PTPN13 contributes to E6 oncogenicity by promoting anchorage-independent growth and EMT in virus-infected cells.

\subsection{NF-אB Pathway}

After exposure to oxidative stress or hypoxia, I $\mathrm{kB} \alpha$ phosphorylation at tyrosine 42 (Y42) releases $\mathrm{NF}-\mathrm{KB}$ that activates transcription of genes involved in apoptosis resistance, cell proliferation, and immune and inflammatory responses [85-88]. Nakai et al. demonstrated that in vitro, IKB $\alpha$ is dephosphorylated at $Y 42$ by PTPN13 [42]. These results were confirmed by Wang et al. in a high-grade serous ovarian carcinoma (HGSOC) cell line (OV-90), in which PTPN13 transfection decreased the levels of $\mathrm{I} \kappa \mathrm{B} \alpha$ phosphorylated at $\mathrm{Y} 42$ and of nuclear NF- $\mathrm{kB}$, in contrast to transfection with PTPN13 siRNA. By using a siRNA against PTPN13 in combination with an inhibitor of I $\mathrm{KB} \alpha$ phosphorylation or an IKB $\alpha$ mutant (Y42A), they confirmed that PTPN13 exerts its tumor suppressive effect by dephosphorylating I $\mathrm{B} \alpha$ at Tyr42 [89]. These results could provide a mechanistic explanation for the work by Castilla et al. 
showing that PTPN13 and PKC- $\delta$ participate in NF- $\mathrm{kB}$ activation in PC3 prostate cancer cells [62] (see Section 2.1).

\subsection{EMT, Cell Migration and Invasion}

Using a PTPN13-transfected hepatocellular carcinoma (HCC) cell line, Zhan et al. suggested that PTPN13 negatively regulates EMT by inhibiting Slug and Snail, two master EMT transcription factors [90]. However, PTPN13 might hinder EMT also through cell junction stabilization via its positive role on desmosome formation, as demonstrated in vitro in MDA-MB-231 breast cancer cells that overexpress PTPN13 and in vivo in a transgenic mouse model that lacks PTPN13 [53]. Although inhibition of miRNA-200c, which targets PTPN13, is associated with EMT [33], an in vivo study found no significant association between downregulation of the miRNA-200 family, PTPN13 expression, and colorectal cancer metastatic potential [91].

PTPN13 is also involved in the regulation of cancer cell migration/invasion via its partner and substrate thyroid hormone receptor interactor 6 (TRIP6, also called ZRP-1) that promotes cell mobility induced by lysophosphatidic acid [41], and activates Wnt/ $\beta$-catenin signaling [92].

Furthermore, siRNA-mediated PTPN13 silencing in the PC3 and DU145 prostate cancer cell lines leads to overexpression of urokinase-type plasminogen activator (uPA) fibrinolytic system components that can degrade the extracellular matrix, thus promoting tumor invasion [93].

In addition, two recent studies illustrate PTPN13 involvement in cell junction maintenance. Fan et al. [22] demonstrated that PTPN13 can dephosphorylate junctional adhesion molecule-A (JAM-A), a transmembrane component of tight junctions, leading to their stabilization. Then, analysis of the interactome of different cell junctions showed that in epithelial cells, PTPN13 is part of the apical marginal zone and interacts with tight junctions and cytoskeleton molecules [94].

In the hematopoietic system, PTPN13 silencing promotes hematopoietic stem cell (HSC) adhesion to bone marrow (thus decreasing their invasiveness), and increases their quiescence [95]. This study, based on previous results by Sardina et al. [43] showing that PTPN13 stabilizes $\beta$-catenin in megakaryocytes, found that inhibition of PTPN13 or $\beta$-catenin in vivo increases HSC adhesion to their niche. The authors hypothesized a negative transcriptional regulation of cell adhesion molecules by $\beta$-catenin, which is positively regulated by PTPN13 [95].

Thus, in solid cancers, PTPN13 inhibits primary tumor cell invasiveness through inhibition of the uPA system, regulation of the main EMT genes, and stabilization of cell junctions. In hematopoietic malignancies, PTPN13 promotes, through $\beta$-catenin, HSC adhesion to their niche, which may later lead to tumor cell invasion.

\subsection{PI3K/PTEN Pathway}

The PI3K pathway is often overactivated in different cancer types, particularly in breast cancer. PTPN13 effect on PI3K activation varies depending on the cell type. In human fibroblasts, HeLa and HEK293T cells, the results obtained by Kuchay et al. suggest that PTPN13 dephosphorylates the p85 regulatory subunit of PI3K that can then interact with F-box and leucine rich repeat protein (FBXL2). This leads to its ubiquitylation and degradation by the proteasome. The negative regulation of the p85 subunit by PTPN13 is important to maintain the insulin receptor substrate-1 (IRS-1)-mediated activation of the PI3K pathway [96].

Conversely, our group demonstrated that PTPN13 inhibits PI3K in MCF7 breast cancer cells [36,97]. PTPN13 is upregulated by antiestrogen agents and is required for apoptosis induction by this treatment [98]. Specifically, in PTPN13-expressing MCF7 cells, incubation with the antiestrogen agent tamoxifen severely reduces IRS- 1 and Akt phosphorylation induced by IGF- 1 and leads to a strong increase in apoptosis. These effects are abolished in cells transfected with PTPN13 antisense, confirming that PTPN13 promotes apoptosis by inhibiting the PI3K survival pathway [97]. In addition, we showed by in vitro and in cellulo substrate trapping, dephosphorylation, and colocalization experiments, that PTPN13 specifically dephosphorylates IRS-1. Very recently, it was demonstrated 
that PTPN13 also acts as a tumor suppressor in clear cell renal cell carcinoma (ccRCC) where lower PTPN13 expression levels predict shorter survival rate. Moreover, in ccRCC cell lines and xenografts, PTPN13 overexpression restricts cancer cell proliferation and invasion through Akt inactivation [99].

PTPN13 can also regulate the PI3K signaling pathway independently of IRS-1 by interacting with Phosphatase and TENsin homolog (PTEN). Yeast two-hybrid and GST pull-down assays showed that the second PDZ domain of PTPN13 can bind to PTEN [28]. Bruurs et al. later demonstrated that this interaction allows the apical localization of PTEN, resulting in the restriction of the apical membrane size in a colorectal cancer cell line. These effects were not modified by inhibition of PTPN13 catalytic activity, suggesting that in this context, PTPN13 functions as an anchor protein. Conversely, PTEN catalytic activity was still required [100].

\section{Transcriptionnal, Post-Transcriptional, Genetic, and Epigenetic Regulation of PTPN13}

PTPN13 expression and activity can be regulated during transcription, via methylation of the CpG islands within its promoter, after transcription by microRNAs or alternative splicing, and also after translation by specific signaling pathways.

\subsection{Transcriptional Regulation}

\subsubsection{Transcriptional Regulation Mediated by Transcription Factors}

Chromatin immunoprecipitation of the PTPN13 promoter revealed that STAT3, HDAC5 [101], and SMYD2 [102] are involved in its transcriptional regulation. The pro-tumor transcription factor STAT3, in combination with the nuclear co-repressor HDAC5, inhibits PTPN13 transcription in squamous cell lung carcinoma cell lines (HCC-1588 and SK-MES-1) after stimulation by the pro-tumor interleukin 6 [101]. The transcription factor SMYD2 is a negative regulator of PTPN13 transcription in polycystic kidney disease [103]. It also promotes tumorigenesis in mice bearing xenografts of triple negative breast cancer cells (MDA-MB231 and MDA-MB468). Similar results were obtained upon PTPN13 silencing by siRNA [102].

More recently, Yan Y. et al. demonstrated that, in HCC, the hepatitis B virus X protein regulates PTPN13 expression via the DNA methyltransferase 3A, which binds to the PTPN13 promoter and induces the hypermethylation of its $\mathrm{CpG}$ islands. This loss of PTPN13 leads to an increase in c-Myc levels and signaling through the loss of its competitive interaction with IGFP2B1 that protects c-Myc mRNA from degradation [104].

On the other hand, the interferon consensus sequence binding protein (ICSBP) transcription factor is a tumor suppressor involved in myelopoiesis, and its expression is repressed in CML [105]. Eklund's group reported that ICSBP negatively regulates PTPN13 in CML cell lines, promoting FAS-mediated apoptosis [106]. They then showed that formation of the Tel-ICSBP-HDAC3 multiprotein complex is required for ICSBP-induced PTPN13 repression. In addition, the Tel-PGFR $\beta$ fusion protein, which results from a chromosomal translocation associated with leukemia, inhibits binding of the Tel/ICSBP/HDAC3 complex to the PTPN13 promoter. This restores PTPN13 expression, causing inhibition of FAS-induced apoptosis in CML [107].

To date, Ewing sarcoma protein-Friend leukemia integration 1 (EWS-FLI1) and homeobox C8 (Hox-C8) are the only known positive regulators of PTPN13 expression. In Ewing's sarcomas, the t(11;22) translocation leads to the expression of the EWS-FLI1 fusion protein, an oncogenic transcription factor that activates PTPN13 transcription, inducing tumor proliferation [108]. The authors then reported a drastic decrease in cell survival after transfection of the PTPN13-C/S mutant in Ewing sarcoma cells. Using substrate trapping in vitro and in vivo in the human Ewing sarcoma TC32 cell line, they identified valosin-containing protein (VCP/p97) as a new PTPN13 substrate. As VCP/p97 phosphorylation is necessary for PTPN13 midbody localization during cell division, a PTPN13 pro-oncogenic role in Ewing sarcoma, mediated through regulation of cell division, could be suggested [39]. 
Hox-C8 is a transcription factor involved in cell differentiation and tissue migration [109]. PTPN13 is one of the genes commonly co-expressed with Hox-C8, and chromatin immunoprecipitation assays confirmed that Hox-C8 binds to the PTPN13 promoter. Moreover, Hox-C8 and PTPN13 expression levels are positively correlated. Hox-C8 overexpression in MC3T3-E1 immature osteoblasts, C3H10T1/2 mesenchymal stem cells, and NIH3T3 fibroblasts positively regulates PTPN13 expression levels, while Hox-C8 knockdown decreases them [109].

Unlike hematopoietic cancers where PTPN13 negative transcriptional regulation has an anti-tumor effect by sensitizing cells to FAS-induced apoptosis, PTPN13 negative transcriptional regulation in solid cancers has a pro-tumor effect through activation of proliferation pathways (Table 3).

Table 3. Transcription factors and co-repressors regulating PTPN13.

\begin{tabular}{cccc}
\hline \multicolumn{4}{c}{ Transcription Factors and Co-Repressors Regulating PTPN13 } \\
\hline Name & Expression/Tumor Type & Effect & Reference \\
\hline STAT3/HDAC5 & $\boldsymbol{\lambda}_{\text {Lung cancers }}$ & $\boldsymbol{y}_{\text {PTPN13 }}$ & {$[101]$} \\
\hline \multirow{2}{*}{ SMYD2 } & $\begin{array}{c}\boldsymbol{\lambda} \text { Polycystic kidney disease } \\
\boldsymbol{\lambda}_{\text {Breast cancer cell lines }}\end{array}$ & $\boldsymbol{y}_{\text {PTPN13 }}$ & {$[103]$} \\
\hline HBx/DNMT3A & $\boldsymbol{\boldsymbol { \lambda }}_{\text {PTPN13 }}$ & {$[102]$} \\
\hline \multirow{2}{*}{ ICSBP } & $\boldsymbol{y}$ Chronic myeloid & $\boldsymbol{y}_{\text {PTPN13 }}$ & {$[104]$} \\
\hline EWS-FLI1 & $\boldsymbol{\lambda}$ Ewing's sarcomas & $\boldsymbol{y}_{\text {PTPN13 }}$ & {$[106]$} \\
\hline Hox-C8 & $\boldsymbol{\lambda}$ Cell differentiation & $\boldsymbol{\lambda}_{\text {PTPN13 }}$ & {$[108]$} \\
\hline
\end{tabular}

\subsubsection{Transcriptional Regulation Mediated by PTPN13 Promoter Methylation}

The PTPN13 and MAPK10 genes share a bi-directional promoter [110] that contains 12 CpG islands [111]. Its methylation is consistently associated with decreased PTPN13 expression [103], and has been observed in many hematologic (94\% of 16 non-Hodgkin lymphoma cell lines, 50\% of 6 Hodgkin lymphoma cell lines) and solid cancer cell lines (67\% of 12 HCC cell lines, 60\% of 10 gastric cancer cell lines, and 30\% of 10 breast cancer cell lines). Similarly, Yeh et al. reported that the PTPN13 promoter is methylated in $66 \%$ of 12 HCC samples without loss of heterozygosity (LOH) of chromosome 4q [104]. Moreover, Wang et al. found that the PTPN13 promoter is methylated in $60 \%$ of 47 diffuse large B cell lymphoma samples, compared with $6.3 \%$ of 16 non-tumor tissue samples [112].

A recent study [62] established four esophageal and Barrett's esophagus adenocarcinoma subtypes based on their genome methylation rate. PTPN13 was among the 69 genes in the highly methylated subtype. Specifically, it was methylated in 56\% of 16 esophageal adenocarcinoma samples, and this was associated with decreased mRNA levels in 75\% of cases. Conversely, the other subtypes did not show any PTPN13 methylation. Moreover, in vitro, shRNA-mediated PTPN13 silencing significantly increases proliferation and migration of SK-GT-4 esophageal adenocarcinoma cells.

In all studies on PTPN13 promoter methylation, PTPN13 expression and activity were restored by incubating cells with 5-azacitidine, a DNA demethylating agent [76,112,113].

\subsection{Post-Transcriptional Regulation}

\subsubsection{Post-Transcriptional Regulation by microRNAs}

MicroRNAs are non-coding RNAs that regulate gene expression through degradation or translation inhibition of their target.

The miR-30 family is composed of five members, a/b/c/d/e (for review: [114]). In tumor samples, miR30-e is decreased in bladder [115], breast [116], and rectal cancer [117], while it is overexpressed in salivary gland cancer [118] and pulmonary adenocarcinoma [119]. Zhuang's laboratory confirmed that miR30-e is significantly overexpressed in lung adenocarcinoma compared with healthy tissue 
samples. They also showed that PTPN13 is a direct target of miR30-e. Tumor growth is promoted in mice xenografted with A549 cells transfected with miR30-e compared with cells transfected with vector alone. Moreover, while PTPN13 overexpression can reverse miR30-e effects on A549 cell growth, siRNA-mediated PTPN13 silencing enhances cell proliferation. This indicates that miR30-e effects are mediated through PTPN13 inhibition [75].

The miR-26 family includes three subtypes with altered expression in various tumors. Xu et al. showed that PTPN13 is a direct target of miR-26a in bronchial adenocarcinoma. Indeed, miR-26a overexpression leads to wild-type PTPN13 protein level reduction, but has no effect on the expression of a PTPN13 variant harboring a mutation in the putative miR-26a binding site. In the SPCA-1 lung adenocarcinoma cell line, siRNA-mediated PTPN13 knockdown mimics the effect of miR26-a, promoting phosphorylation of SRC, Akt, and ERK [74], supporting miR26a oncogenic role in bronchial adenocarcinoma.

The miR-200 family contains five subtypes (miR-200a/b/c, miR-141, and miR-429), and is involved in maintaining the epithelial phenotype [120]. Schickel et al. demonstrated that miR-200c decreases PTPN13 transcription by $60 \%$ in HEK293 cells. Furthermore, PTPN13 repression mediated by miR-200 increases sensitivity to FAS-induced apoptosis in tumor cell lines with mesenchymal features [56] (see chapter A).

The miR-185 family is overexpressed in bladder and kidney cancers and targets the PTPN13 and PTEN genes. However, their effects have not been studied in vivo yet [121] (Table 4).

Table 4. miRNA targeting PTPN13.

\begin{tabular}{cccc}
\hline \multicolumn{4}{c}{ miRNA Targeting PTPN13 } \\
\hline Name & Tumor Type & miRNA Expression & Reference \\
\hline miR-26-a & Lung cancers & Overexpression & {$[74]$} \\
\hline miR30-e & Lung cancers & Overexpression & {$[75]$} \\
\hline miR-200c & Various cancers & Loss of expression & {$[56]$} \\
\hline miR-185 & Bladder and Kidney Cancers & Overexpression & {$[121]$} \\
\hline
\end{tabular}

\subsubsection{Post-Transcriptional Regulation by Alternative Splicing}

Although there are four PTPN13 isoforms [122], the regulation and consequences of PTPN13 alternative splicing have been rarely explored. In the only published study, the consequences of hypoxia on the genome of prostate adenocarcinoma cells were analyzed by next generation sequencing. They found a decrease of more than 25\% in PTPN13 exon inclusion rate, but the functions of its spliced isoforms remain unknown [123].

\subsection{Post-Translational Regulation}

Similarly, PTPN13 post-translational regulation remains largely unexplored. To our knowledge, only one study has been published. Wang et al found that in a mouse brain after traumatic brain injury, calpain-2 inhibits PTPN13 activity by upstream cleavage of its catalytic domain, leading to ABL-mediated phosphorylation of the microtubule-associated tau protein [30].

It would be of particular interest to study the role of the large number of PTPN13 post-translationally modified residues found in global proteomic studies, as illustrated in the www.phosphosite.org database, but their function and significance remain to be elucidated.

\section{Medical Implication of PTPN13}

\subsection{Prognostic Marker of Survival}

Several retrospective clinical studies analyzed PTPN13 prognostic value in different diseases. 
In ovarian cancer, a first study of 95 specimens with different histological subtypes found no association between PTPN13 expression and survival at 2, 3, and 5 years [124]. However, two studies only on HGSOC, the most frequent ovarian cancer subtype, highlighted a correlation between high PTPN13 protein and mRNA expression and better prognosis in 97 and 58 HGSOC samples, respectively $(p=0.042$ and $p=0.03)[89,125]$. They also observed that PTPN13 expression levels are reduced in tumor tissues compared with normal tissues.

In breast cancer ( $\mathrm{n}=291$ samples), we showed that high PTPN13 expression, measured by RT/PCR, is associated with better prognosis ( $p=0.01$ and $R R=0.48$ in multivariate analysis) [126]. In a second study, in which we analyzed 24 breast cancer samples by immunohistochemistry (IHC), we observed a progressive decrease in PTPN13 expression from normal to metastatic tissue samples [38].

In prostate cancer samples $(\mathrm{n}=76)$, PTPN13 expression, estimated by IHC, was inversely correlated with the Gleason score $(p<0.05)$. PTPN13 was overexpressed in well-differentiated tumors (low Gleason score), and downregulated in high-grade prostate tumors [62].

Three of four studies on lung cancer [squamous lung cell carcinoma (LSCC) [127], adenocarcinoma [75], and non-small-cell lung carcinoma (NSCLC) [67]] found a significant decrease in PTPN13 expression in tumors compared with normal tissues. Two of these studies also evaluated PTPN13 prognostic value, and found that RNA expression is associated with improved survival in 27 patients $(\mathrm{HR}=0.28 p=0.02)$ [128], and its protein expression with a lower aggressiveness in 91 primary LSCC samples (negative correlation with size, grade, and lymph node metastases, $p<0.001$ for all three criteria) [127]. The fourth study [128] did not find any significant difference in PTPN13 expression between adenocarcinoma samples from non-smoking patients and adjacent normal tissues.

A study on 282 HCC samples demonstrated that elevated PTPN13 expression (by IHC) is associated with better prognosis $(p=0.034)$ [90].

In primary Ewing sarcoma $(n=144)$, PTPN13 was detected by IHC in $80 \%$ of tumor specimens, but its level was not associated with survival [129]. Interestingly, it was not reported in normal human bone samples.

In glioblastoma, PTPN13 RNA level was increased compared with normal brain, but this finding was based only on three samples and should be confirmed [130].

In conclusion, compared with healthy tissues, PTPN13 expression is decreased in all tumor types that have been studied, except for glioblastoma. As PTPN13 expression is not detectable in bone, its relative variation in Ewing sarcoma cannot be assessed. Overall, PTPN13 expression is linked to less aggressive tumors and better patient survival. PTPN13 is considered an independent biomarker of good prognosis in several solid tumor types, such as breast cancer [126], HGSOC [89,125], and HCC [90]. However, all these results are from retrospective studies, and should be confirmed in prospective studies.

Noteworthy, many mechanistic studies that indicate a negative role of PTPN13 in FAS-induced apoptosis and suggest a pro-tumor function were performed in hematopoietic cancers. To our knowledge, no clinical study investigated the prognostic role of PTPN13 expression in these cancers.

\subsection{PTPN13 and Drug Sensitivity}

As PTPN13 induces resistance to FAS-mediated apoptosis, several studies evaluated whether resistance to cancer treatment is associated with PTPN13 expression (see chapter 2.1). It is important to note that the results presented below were all obtained in vitro. In colon cancer cells, where FAS receptor is strongly expressed [131], a study showed that oxaliplatin induces PTPN13 expression, thereby protecting cells from apoptosis. PTPN13 silencing by siRNA combined with oxaliplatin improves sensitivity to chemotherapy by increasing FAS-induced apoptosis [55]. In line with these data, inhibition of the PTPN13/FAS interaction with the SLV peptide in PTPN13-overexpressing CD133+ colon cancer stem cells increases their sensitivity to oxaliplatin, restoring FAS-induced apoptosis [51].

Similar observations have been made using CML stem cells that overexpress PTPN13 and exhibit resistance to tyrosine kinase inhibitors (TKI). The combination of TKI against BCR/ABL and FAS 
inhibition with the SLV peptide restores sensitivity to FAS-induced apoptosis and to TKIs in such cells [61].

On the other hand, in NSCLC cell lines (SPCA1 and PC-9), PTPN13 increases the sensitivity to an anti-EGFR TKI (gefitinib). Indeed, PTPN13 inhibition by miR-26a has been associated with resistance to gefitinib in vitro and in vivo, implying in this case the ability of PTPN13 to inhibit SRC [74].

Ephrin B1 also is implicated in the response to anti-tumor treatments. Indeed, when dephosphorylated, ephrin B1 can bind to mitotic spindle microtubules, thus increasing the sensitivity to paclitaxel in head and neck squamous cell carcinoma and breast cancer cell lines [132]. Conversely, when phosphorylated, ephrin B1 is excluded from the spindle and is associated with resistance to paclitaxel in epithelial cancer cell lines. Ephrin B1 dephosphorylation is directly regulated by PTPN13, and this may explain why tumors with low PTPN13 expression are resistant to paclitaxel [132].

Another study showed that the newly identified ephrin B1/ErbB/PTPN13 signaling pathway [71] is implicated in the resistance to a monoclonal antibody against ERBB1 (cetuximab) in HNSCC. Cetuximab blocks ERBB1, but does not prevent ephrin B1 activation or ERK phosphorylation. This new signaling pathway, regulated by PTPN13, allows cells to escape treatment-induced pressure by shifting from ERBB1 to ephrinB1 signaling [71]. This suggests a potential role for the ephrinB1/ErbB/PTPN13 axis in HNSCC resistance to some EGF-R inhibitors.

A recent study demonstrated PTPN13 involvement in cisplatin sensitivity of HNSCC cell lines (WSU-HN6 and CAL-27) where cancer-derived IgG inhibition upregulates PTPN13, resulting in the inhibition of the SRC/PKD1/AKT pathway [133].

In summary, depending on the tumor type, PTPN13 may regulate resistance to anti-cancer therapies through its anti-apoptotic role via the FAS pathway, or through regulation of secondary EGFR pathways (ephrinB1/ErbB and SRC/PKD1/AKT), or through an indirect action on microtubules mediated by ephrinB1.

\subsection{PTPN13 Gene Alterations}

\subsubsection{Loss of Heterozygosity (LOH)}

PTPN13 gene deletion has been observed in 37\% of NSCLC [67], with higher prevalence in metastatic than non-metastatic lung cancer [134]. Similarly, PTPN13 LOH has been reported in $67 \%$ of HGSOC [135], and PTPN13 bi-allelic loss in 26\% of NSCLC samples [67].

\subsubsection{Single Nucleotide Polymorphisms (SNP)}

Besides LOH, other genetic variations may be relevant to the residual allele, particularly SNPs [136].

The Y2081D Tyr2081Asp ( $>$ > G), rs989902 (rs for SNP reference), in exon 39, near the PTPN13 phosphatase domain [137], is associated with colorectal cancer in Polish patients (relative risk compared to the "wild-type" genotype: 2.087) [138], and with HNSCC in American patients (Odds Ratio, $\mathrm{OR},=1.26$ ) [139]. A meta-analysis of data from Caucasian and Asian patients confirmed its association with HNSCC $(\mathrm{OR}=1.23)$, but a protective role was attributed to PTPN13 in colorectal cancer $(\mathrm{OR}=0.51)$. These apparently contradictory results might be explained by the different populations. In breast cancer, this meta-analysis found a protective role for this SNP $(\mathrm{OR}=0.63)$, as well as a Chinese study on the $\mathrm{C} / \mathrm{A}$ and $\mathrm{G} / \mathrm{C}$ genotypes of this SNP $(\mathrm{OR}=0.63$ and $\mathrm{OR}=0.66)$ [140].

The I1522M Ile1522Met (A > G), rs2230600, in exon 29 within the third PTPN13 PDZ domain, has been associated with HNSCC occurrence (OR = 1.89) [137]. Mita et al. [137] found an increased risk of lung, head, and neck cancer, and colorectal cancer when at least one of these two SNPs is present (adjusted OR = 3.36-13.75). Conversely, esophageal cancer was not associated with any of them.

The effects of these two SNPs on PTPN13 protein expression remain unknown. Conversely, the tE2455D and Y2260WX SNPs in the catalytic domain of PTPN13 that have been identified in colorectal cancer induce a loss of 50 to almost 100\%, respectively, of the phosphatase activity [37]. 
In addition, the nonsense Tyr1758*** $(\mathrm{T}>\mathrm{A})$ and missense Glu745Gln mutations have been found in hepatitis B virus-induced HCC samples, and the L1424P false-sense mutation, which is located in a protein-interacting PDZ domain (genomic position 87687597), may affect PTPN13 function. Around $6 \%$ of TCGA gastric cancer samples harbor PTPN13 mutations that have been associated with poor prognosis [141].

In 262 patients with familial lung cancer, a non-synonymous PTPN13 exon variant (rs115836094) at 4q21.3-28.3 could be involved in carcinogenesis [142]. Moreover, $8 \%$ of NSCLC samples harbored false-sense PTPN13 mutations with unknown functions (e.g., A808C leading to N270H in exon 7, and G1925A, leading to R482Q in exon 10) [50]. Conversely, sequencing of PTPN13 exon 7, which could be involved in the regulation of FAS-related apoptosis, in 103 colorectal cancer samples did not reveal any mutation [143].

Overall, approximately 7-8\% of lung cancer [67,128] and 20\% of HPV-negative HNSCC [144] samples harbor PTPN13 mutations. A mutational analysis of data from a tyrosine phosphatome-wide study of 157 CRC samples showed that PTPN13 is the second most commonly mutated phosphatase in these cancers ( $n=15$ tumors with a mutation; $9 \%$ of the entire sample) [145].

PTPN13 genetic polymorphisms need to be better investigated. Nevertheless, all analyzed mutations have an inhibitory effect on PTPN13 activity, and their presence appears to be associated with poor prognosis in lung cancer $(p=0.02)$ [128] and possibly in gastric cancer [141].

\subsection{Bio-Informatic Analysis of the PTPN13 Gene Regulatory Network}

In 2015, Yu et al. [146] created a gene regulatory network using an innovative modeling technique (statistical completion of a partially identified graph), that is based on classical statistical data and that integrates already known mechanistic data, such as protein interactions and transcription factor binding sites. They identified PTPN13 as a new lung cancer pivotal gene and validated its prognostic importance retrospectively in four independent lung cancer datasets ( $n=529$ patients). The decrease in PTPN13 expression was associated with poorer prognosis.

Finally, genetic studies support the notion of PTPN13 loss of expression/function in cancer, through LOH and/or SNPs. The previously described epigenetic mechanisms have the same negative consequences on its expression.

Altogether, these data bring weight to the hypothesis of a primary tumor suppressor role for the PTPN13 phosphatase.

\section{Conclusions}

The work of the last 25 years on PTPN13 reveals that this phosphatase is involved in many physiological mechanisms, with a variable importance depending on the cell type.

In solid tumors, PTPN13 tumor suppressor role, via inhibition of pathways involved in cell proliferation and migration, seems to be confirmed by clinical studies. Conversely, its potential pro-oncogenic role in hematologic malignancies, via resistance to FAS-induced apoptosis, needs to be investigated at the clinical level.

Interestingly, recent studies on PTPN13 highlight its function as a stabilizer of epithelial cell junctions, a role that in epithelial tissues, places PTPN13 at the interface between cell migration and cell death and should be better assessed in the future $[30,83,84]$.

Finally, although PTPN13 is primarily studied in cancer, its roles in multiple signaling pathways suggest its implication also in other pathologies, for instance, neurodegenerative diseases where recent studies pointed to a potential role in tau phosphorylation [147].

Funding: This research was funded by "Ligue Nationale Contre le Cancer" grant number "GARD R20025FF", L.A. is a recipient of "Université de Médecine de Montpellier" fellowship and S.M. of "Vivre en solidarité" fellowship (Lebanon).

Acknowledgments: The authors acknowledge Carole Puech for its technical support. 
Conflicts of Interest: The authors declare no conflict of interest.

\section{References}

1. Maekawa, K.; Imagawa, N.; Nagamatsu, M.; Harada, S. Molecular cloning of a novel protein-tyrosine phosphatase containing a membrane-binding domain and GLGF repeats. FEBS Lett. 1994, 337, 200-206. [CrossRef]

2. Banville, D.; Ahmad, S.; Stocco, R.; Shen, S.H. A novel protein-tyrosine phosphatase with homology to both the cytoskeletal proteins of the band 4.1 family and junction-associated guanylate kinases. J. Biol. Chem. 1994, 269, 22320-22327. [PubMed]

3. Saras, J.; Claesson-Welsh, L.; Heldin, C.H.; Gonez, L.J. Cloning and characterization of PTPL1, a protein tyrosine phosphatase with similarities to cytoskeletal-associated proteins. J. Biol. Chem. 1994, 269, 24082-24089. [PubMed]

4. Sato, T.; Irie, S.; Kitada, S.; Reed, J.C. FAP-1: A protein tyrosine phosphatase that associates with Fas. Science 1995, 268, 411-415. [CrossRef] [PubMed]

5. Julien, S.G.; Dubé, N.; Hardy, S.; Tremblay, M.L. Inside the human cancer tyrosine phosphatome. Nat. Rev. Cancer 2011, 11, 35-49. [CrossRef] [PubMed]

6. Blanchetot, C.; Chagnon, M.; Dube, N.; Halle, M.; Tremblay, M.L. Substrate-trapping techniques in the identification of cellular PTP targets. Methods 2005, 35, 44-53. [CrossRef]

7. Lee, S.H.; Shin, M.S.; Park, W.S.; Kim, S.Y.; Kim, H.S.; Lee, J.-H.; Han, S.Y.; Lee, H.K.; Park, J.Y.; Oh, R.R.; et al. Immunohistochemical localization of FAP-1, an inhibitor of Fas-mediated apoptosis, in normal and neoplastic human tissues. APMIS 1999, 107, 1101-1108. [CrossRef]

8. Herrmann, L.; Dittmar, T.; Erdmann, K.S. The Protein Tyrosine Phosphatase PTP-BL Associates with the Midbody and Is Involved in the Regulation of Cytokinesis V. Mol. Biol. Cell 2003, 14, 230-240. [CrossRef]

9. Maagdenberg, A.M.J.M.V.D.; Weghuis, D.O.; Rijss, J.; Merkx, G.F.; Wieringa, B.; Van Kessel, A.G.; Hendriksa, W. The gene (PTPN13) encoding the protein tyrosine phosphatase PTP-BL/PTP-BAS is located in mouse chromosome region 5E/F and human chromosome region 4q21. Cytogenet. Genome Res. 1996, 74, 153-155. [CrossRef]

10. Mangeat, P.; Roy, C.; Martin, M. ERM proteins in cell adhesion and membrane dynamics. Trends Cell Biol. 1999, 9, 187-192. [CrossRef]

11. Hendriks, W.J.; Schepens, J.; Bächner, D.; Rijss, J.; Zeeuwen, P.L.J.M.; Zechner, U.; Hameister, H.; Wieringa, B. Molecular cloning of a mouse epithelial protein-tyrosine phosphatase with similarities to submembranous proteins. J. Cell. Biochem. 1995, 59, 418-430. [CrossRef] [PubMed]

12. Cuppen, E.; Wijers, M.; Schepens, J.; Fransen, J.; Wieringa, B.; Hendriks, W. A FERM domain governs apical confinement of PTP-BL in epithelial cells. J. Cell Sci. 1999, 112, 3299-3308. [PubMed]

13. Bompard, G.; Martin, M.; Roy, C.; Vignon, F.; Freiss, G. Membrane targeting of protein tyrosine phosphatase PTPL1 through its FERM domain via binding to phosphatidylinositol 4,5-biphosphate. J. Cell Sci. 2003, 116, 2519-2530. [CrossRef]

14. Kimber, W.A.; Deak, M.; Prescott, A.; Alessi, D.R. Interaction of the protein tyrosine phosphatase PTPL1 with the PtdIns(3,4)P2-binding adaptor protein TAPP1. Biochem. J. 2003, 376, 525-535. [CrossRef] [PubMed]

15. Hagemann, N.; Ackermann, N.; Christmann, J.; Brier, S.; Yu, F.; Erdmann, K.S. The serologically defined colon cancer antigen-3 interacts with the protein tyrosine phosphatase PTPN13 and is involved in the regulation of cytokinesis. Oncogene 2012, 32, 4602-4613. [CrossRef] [PubMed]

16. Fanning, A.S.; Van Itallie, C.M. PDZ domains: Fundamental building blocks in the organization of protein complexes at the plasma membrane. J. Clin. Investig. 1999, 103, 767-772. [CrossRef]

17. Freiss, G.; Chalbos, D. PTPN13/PTPL1: An Important Regulator of Tumor Aggressiveness. Anti Cancer Agents Med. Chem. 2011, 11, 78-88. [CrossRef]

18. Kawano, S.; Ikeda, W.; Kishimoto, M.; Ogita, H.; Takai, Y. Silencing of ErbB3/ErbB2 Signaling by Immunoglobulin-like Necl-2. J. Biol. Chem. 2009, 284, 23793-23805. [CrossRef]

19. Cuppen, E.; Van Ham, M.; Pepers, B.; Wieringa, B.; Hendriks, W.J. Identification and molecular characterization of BP75, a novel bromodomain-containing protein. FEBS Lett. 1999, 459, 291-298. [CrossRef] 
20. Maekawa, K.; Imagawa, N.; Naito, A.; Harada, S.; Yoshie, O.; Takagi, S. Association of protein-tyrosine phosphatase PTP-BAS with the transcription- factor-inhibitory protein I $\mathrm{B} \alpha$ through interaction between the PDZ1 domain and ankyrin repeats. Biochem. J. 1999, 337. [CrossRef]

21. Zhang, W.; Tong, Q.; Conrad, K.; Wozney, J.; Cheung, J.Y.; Miller, B.A. Regulation of TRP channel TRPM2 by the tyrosine phosphatase PTPL1. Am. J. Physiol. Physiol. 2007, 292, C1746-C1758. [CrossRef] [PubMed]

22. Fan, S.; Weight, C.M.; Luissint, A.-C.; Hilgarth, R.S.; Brazil, J.C.; Ettel, M.; Nusrat, A.; Parkos, C.A. Role of JAM-A tyrosine phosphorylation in epithelial barrier dysfunction during intestinal inflammation. Mol. Biol. Cell 2019, 30, 566-578. [CrossRef] [PubMed]

23. Cuppen, E.; Van Ham, M.; Wansink, D.G.; De Leeuw, A.; Wieringa, B.; Hendriks, W. The zyxin-related protein TRIP6 interacts with PDZ motifs in the adaptor protein RIL and the protein tyrosine phosphatase PTP-BL. Eur. J. Cell Biol. 2000, 79, 283-293. [CrossRef]

24. Irie, S.; Hachiya, T.; Rabizadeh, S.; Maruyama, W.; Mukai, J.; Li, Y.; Reed, J.C.; Bredesen, D.E.; Sato, T.-A. Functional interaction of Fas-associated phosphatase-1 (FAP-1) with p75NTR and their effect on NF- $\mathrm{kB}$ activation. FEBS Lett. 1999, 460, 191-198. [CrossRef]

25. Erdmann, K.S.; Kuhlmann, J.; Lessmann, V.; Herrmann, L.; Eulenburg, V.; Müller, O.; Heumann, R. The Adenomatous Polyposis Coli-protein (APC) interacts with the protein tyrosine phosphatase PTP-BL via an alternatively spliced PDZ domain. Oncogene 2000, 19, 3894-3901. [CrossRef] [PubMed]

26. Cuppen, E.; Gerrits, H.; Pepers, B.; Wieringa, B.; Hendriks, W.J. PDZ Motifs in PTP-BL and RIL Bind to Internal Protein Segments in the LIM Domain Protein RIL. Mol. Biol. Cell 1998, 9, 671-683. [CrossRef] [PubMed]

27. Saras, J.; Engström, U.; Góñez, L.J.; Heldin, C.-H. Characterization of the interactions between PDZ domains of the protein-tyrosine phosphatase PTPL1 and the carboxyl-terminal tail of Fas. J. Biol. Chem. 1997, 272, 20979-20981. [CrossRef]

28. Sotelo, N.S.; Schepens, J.T.; Valiente, M.; Hendriks, W.J.; Pulido, R. PTEN-PDZ domain interactions: Binding of PTEN to PDZ domains of PTPN13. Methods 2015, 77-78, 147-156. [CrossRef]

29. Gross, C.; Heumann, R.; Erdmann, K.S. The protein kinase C-related kinase PRK2 interacts with the protein tyrosine phosphatase PTP-BL via a novel PDZ domain binding motif. FEBS Lett. 2001, 496, 101-104. [CrossRef]

30. Wang, Y.; Hall, R.A.; Lee, M.; Kamgar-Parsi, A.; Bi, X.; Baudry, M. The tyrosine phosphatase PTPN13/FAP-1 links calpain-2, TBI and tau tyrosine phosphorylation. Sci. Rep. 2017, 7, 11771. [CrossRef]

31. Saras, J.; Franzén, P.; Aspenström, P.; Hellman, U.; Gonez, L.J.; Heldin, C.-H. A Novel GTPase-activating Protein for Rho Interacts with a PDZ Domain of the Protein-tyrosine Phosphatase PTPL1. J. Biol. Chem. 1997, 272, 24333-24338. [CrossRef] [PubMed]

32. Lin, D.; Gish, G.D.; Songyang, Z.; Pawson, T. The Carboxyl Terminus of B Class Ephrins Constitutes a PDZ Domain Binding Motif. J. Biol. Chem. 1999, 274, 3726-3733. [CrossRef] [PubMed]

33. Nakahira, M.; Tanaka, T.; Robson, B.E.; Mizgerd, J.P.; Grusby, M.J. Regulation of Signal Transducer and Activator of Transcription Signaling by the Tyrosine Phosphatase PTP-BL. Immunity 2007, 26, 163-176. [CrossRef] [PubMed]

34. Glondu-Lassis, M.; Dromard, M.; Chavey, C.; Puech, C.; Fajas, L.; Hendriks, W.J.; Freiss, G. Downregulation of protein tyrosine phosphatase PTP-BL represses adipogenesis. Int. J. Biochem. Cell Biol. 2009, 41, 2173-2180. [CrossRef] [PubMed]

35. Wansink, D.G.; Peters, W.; Schaafsma, I.; Sutmuller, R.P.M.; Oerlemans, F.; Adema, G.J.; Wieringa, B.; Van Der Zee, C.E.E.M.; Hendriks, W. Mild impairment of motor nerve repair in mice lacking PTP-BL tyrosine phosphatase activity. Physiol. Genom. 2004, 19, 50-60. [CrossRef] [PubMed]

36. Dromard, M.; Bompard, G.; Glondu-Lassis, M.; Puech, C.; Chalbos, D.; Freiss, G. The Putative Tumor Suppressor GenePTPN13/PTPL1Induces Apoptosis through Insulin Receptor Substrate-1 Dephosphorylation. Cancer Res. 2007, 67, 6806-6813. [CrossRef]

37. Zhu, J.-H.; Chen, R.; Yi, W.; Cantin, G.T.; Fearns, C.; Yang, Y.; Yates, J.R.; Lee, J.-D. Protein tyrosine phosphatase PTPN13 negatively regulates Her2/ErbB2 malignant signaling. Oncogene 2007, 27, 2525-2531. [CrossRef]

38. Glondu-Lassis, M.; Dromard, M.; Lacroix-Triki, M.; Nirdé, P.; Puech, C.; Knani, D.; Chalbos, D.; Freiss, G. PTPL1/PTPN13 regulates breast cancer cell aggressiveness through direct inactivation of Src kinase. Cancer Res. 2010, 70, 5116-5126. [CrossRef] 
39. Abaan, O.D.; Hendriks, W.J.; Üren, A.; Toretsky, J.A.; Erkizan, H.V.P. Valosin containing protein (VCP/p97) is a novel substrate for the protein tyrosine phosphatase PTPL1. Exp. Cell Res. 2012, 319, 1-11. [CrossRef]

40. Palmer, A.; Zimmer, M.; Erdmann, K.S.; Eulenburg, V.; Porthin, A.; Heumann, R.; Deutsch, U.; Klein, R. EphrinB Phosphorylation and Reverse Signaling. Mol. Cell 2002, 9, 725-737. [CrossRef]

41. Lai, Y.-J.; Lin, W.-C.; Lin, F.-T. PTPL1/FAP-1 negatively regulates TRIP6 function in lysophosphatidic acid-induced cell migration. J. Biol. Chem. 2007, 282, 24381-24387. [CrossRef] [PubMed]

42. Nakai, Y.; Irie, S.; Sato, T.-A. Identification of $\mathrm{I} \kappa \mathrm{B} \alpha$ as a substrate of Fas-associated phosphatase-1. JBIC J. Biol. Inorg. Chem. 2000, 267, 7170-7175. [CrossRef] [PubMed]

43. Sardina, J.L.; López-Ruano, G.; Prieto-Bermejo, R.; Sánchez-Sánchez, B.; Pérez-Fernández, A.; Sánchez-Abarca, L.I.; Pérez-Simón, J.A.; Quintales, L.; Sánchez-Yagüe, J.; Llanillo, M.; et al. PTPN13 regulates cellular signalling and $\beta$-catenin function during megakaryocytic differentiation. Biochim. Biophys. Acta Mol. Cell Res. 2014, 1843, 2886-2899. [CrossRef] [PubMed]

44. Bidère, N.; Su, H.C.; Lenardo, M.J. Genetic Disorders of Programmed Cell Death in the Immune System. Annu. Rev. Immunol. 2006, 24, 321-352. [CrossRef] [PubMed]

45. Ivanov, V.N.; Bergami, P.L.; Maulit, G.; Sato, T.-A.; Sassoon, D.; Ronai, Z.A. FAP-1 Association with Fas (Apo-1) Inhibits Fas Expression on the Cell Surface. Mol. Cell. Biol. 2003, 23, 3623-3635. [CrossRef] [PubMed]

46. Li, Y.; Kanki, H.; Hachiya, T.; Ohyama, T.; Irie, S.; Tang, G.-L.; Mukai, J.; Sato, T.-A. Negative regulation of Fas-mediated apoptosis by FAP-1 in human cancer cells. Int. J. Cancer 2000, 87, 473-479. [CrossRef]

47. Yanagisawa, J.; Takahashi, M.; Kanki, H.; Yano-Yanagisawa, H.; Tazunoki, T.; Sawa, E.; Nishitoba, T.; Kamishohara, M.; Kobayashi, E.; Kataoka, S.; et al. The Molecular Interaction of Fas and FAP-1. J. Biol. Chem. 1997, 272, 8539-8545. [CrossRef]

48. Yao, H.; Song, E.; Chen, J.; Hamar, P. Expression of FAP-1 by human colon adenocarcinoma: Implication for resistance against Fas-mediated apoptosis in cancer. Br. J. Cancer 2004, 91, 1718-1725. [CrossRef]

49. Myc, A.; Arscott, P.L.; Bretz, J.D.; Thompson, N.W.; Baker, J.R. Characterization of FAP-1 Expression and Function in Thyroid Follicular Cells. Endocrinology 1999, 140, 5431-5434. [CrossRef]

50. Takahashi, M.; Kataoka, S. Development of anti cancer drugs targeted on Fas-mediated apoptosis signal. Cancer Chemother. 1997, 24, 222-228.

51. Huang, W.; Bei, L.; Eklund, E.A. Inhibition of Fas associated phosphatase 1 (Fap1) facilitates apoptosis of colon cancer stem cells and enhances the effects of oxaliplatin. Oncotarget 2018, 9, 25891-25902. [CrossRef] [PubMed]

52. Gagnoux-Palacios, L.; Awina, H.; Audebert, S.; Rossin, A.; Mondin, M.; Borgese, F.; Planas-Botey, C.; Mettouchi, A.; Borg, J.-P.; Hueber, A.-O. Cell polarity and adherens junction formation inhibit epithelial Fas cell death receptor signaling. J. Cell Biol. 2018, 217, 3839-3852. [CrossRef] [PubMed]

53. Hamyeh, M.; Bernex, F.; Larive, R.M.; Naldi, A.; Urbach, S.; Simony-Lafontaine, J.; Puech, C.; Bakhache, W.; Solassol, J.; Coopman, P.J.; et al. PTPN13 induces cell junction stabilization and inhibits mammary tumor invasiveness. Theranostics 2020, 10, 1016-1032. [CrossRef] [PubMed]

54. Ungefroren, P.D.R.N.H.; Kruse, M.L.; Trauzold, A.; Roeschmann, S.; Roeder, C.; Arlt, A.; Henne-Bruns, D.; Kalthoff, H. FAP-1 in pancreatic cancer cells: Functional and mechanistic studies on its inhibitory role in CD95-mediated apoptosis. J. Cell Sci. 2001, 114, 2735-2746. [PubMed]

55. Xiao, Z.-Y.; Wu, W.; Eagleton, N.; Chen, H.-Q.; Shao, J.; Teng, H.; Liu, T.-H.; Jiang, Z.-M.; Yao, H.-R. Silencing Fas-associated phosphatase 1 expression enhances efficiency of chemotherapy for colon carcinoma with oxaliplatin. World J. Gastroenterol. 2010, 16, 112-118. [PubMed]

56. Schickel, R.; Park, S.-M.; Murmann, A.E.; Peter, M.E. mir-200c Regulates Induction of Apoptosis through CD95 by Targeting FAP-1. Mol. Cell 2010, 38, 908-915. [CrossRef]

57. Neznanov, N.; Neznanova, L.; Angres, B.; Gudkov, A.V. Serologically Defined Colon Cancer Antigen 3 Is Necessary for the Presentation of TNF Receptor 1 on Cell Surface. DNA Cell Biol. 2005, 24, 777-785. [CrossRef]

58. Sharma, S.; Carmona, A.; Skowronek, A.; Yu, F.; Collins, M.O.; Naik, S.; Murzeau, C.M.; Tseng, P.-L.; Erdmann, K.S. Apoptotic signalling targets the post-endocytic sorting machinery of the death receptor Fas/CD95. Nat. Commun. 2019, 10,1-16. [CrossRef]

59. Huang, W.; Bei, L.; Eklund, E.A. Fas-associated phosphatase 1 mediates Fas resistance in myeloid progenitor cells expressing the Bcr-abl oncogene. Leuk. Lymphoma 2013, 54, 619-630. [CrossRef] 
60. Huang, W.; Bei, L.; Eklund, E.A. Fas-associated Phosphatase 1 (Fap1) Influences $\beta$ Catenin Activity in Myeloid Progenitor Cells Expressing the Bcr-abl Oncogene. J. Biol. Chem. 2013, 288, 12766-12776. [CrossRef]

61. Huang, W.; Luan, C.-H.; Hjort, E.E.; Bei, L.; Mishra, R.; Sakamoto, K.M.; Platanias, L.C.; Eklund, E.A. The role of Fas-associated phosphatase 1 in leukemia stem cell persistence during tyrosine kinase inhibitor treatment of chronic myeloid leukemia. Leukemia 2016, 30, 1502-1509. [CrossRef] [PubMed]

62. Castilla, C.; Chinchón, D.; Medina, R.; Torrubia, F.J.; Japón, M.A.; Sáez, C. PTPL1 and PKC $\delta$ contribute to proapoptotic signalling in prostate cancer cells. Cell Death Dis. 2013, 4, e576. [CrossRef] [PubMed]

63. Winterhoff, B.J.; Arlt, A.; Duttmann, A.; Ungefroren, H.; Schäfer, H.; Kalthoff, H.; Kruse, M.-L. Characterisation of FAP-1 expression and CD95 mediated apoptosis in the A818-6 pancreatic adenocarcinoma differentiation system. Differentiation 2012, 83, 148-157. [CrossRef] [PubMed]

64. Guarino, M. Src signaling in cancer invasion. J. Cell. Physiol. 2009, 223, 14-26. [CrossRef] [PubMed]

65. Wee, P.; Wang, Z. Epidermal Growth Factor Receptor Cell Proliferation Signaling Pathways. Cancers 2017, 9, 52. [CrossRef]

66. Holen, H.L.; Shadidi, M.; Narvhus, K.; Kjøsnes, O.; Tierens, A.; Aasheim, H.-C. Signaling through ephrin-A ligand leads to activation of Src-family kinases, Akt phosphorylation, and inhibition of antigen receptor-induced apoptosis. J. Leukoc. Biol. 2008, 84, 1183-1191. [CrossRef]

67. Scrima, M.; De Marco, C.; De Vita, F.; Fabiani, F.; Franco, R.; Pirozzi, G.; Rocco, G.; Malanga, D.; Viglietto, G. The Nonreceptor-Type Tyrosine Phosphatase PTPN13 Is a Tumor Suppressor Gene in Non-Small Cell Lung Cancer. Am. J. Pathol. 2012, 180, 1202-1214. [CrossRef]

68. Zhang, Y.; Tu, Y.; Zhao, J.; Chen, K.; Wu, C. Reversion-induced LIM interaction with Src reveals a novel Src inactivation cycle. J. Cell Biol. 2009, 184, 785-792. [CrossRef]

69. Lucci, M.A.; Orlandi, R.; Triulzi, T.; Tagliabue, E.; Balsari, A.; Villa-Moruzzi, E. Expression Profile of Tyrosine Phosphatases in HER2 Breast Cancer Cells and Tumors. Cell. Oncol. 2010, 32, 361-372.

70. Vermeer, P.D.; Bell, M.; Lee, K.; Vermeer, D.W.; Wieking, B.G.; Bilal, E.; Bhanot, G.; Drapkin, R.I.; Ganesan, S.; Klingelhutz, A.J.; et al. ErbB2, EphrinB1, Src Kinase and PTPN13 Signaling Complex Regulates MAP Kinase Signaling in Human Cancers. PLoS ONE 2012, 7, e30447. [CrossRef]

71. Vermeer, P.D.; Colbert, P.L.; Wieking, B.G.; Vermeer, D.W.; Lee, J.H. Targeting ERBB Receptors Shifts Their Partners and Triggers Persistent ERK Signaling through a Novel ERBB/EFNB1 Complex. Cancer Res. 2013, 73, 5787-5797. [CrossRef] [PubMed]

72. Grandis, J.R.; Tweardy, D.J. Elevated levels of transforming growth factor alpha and epidermal growth factor receptor messenger RNA are early markers of carcinogenesis in head and neck cancer. Cancer Res. 1993, 53, 3579-3584. [PubMed]

73. Spanos, W.C.; Hoover, A.; Harris, G.F.; Wu, S.; Strand, G.L.; Anderson, M.E.; Klingelhutz, A.J.; Hendriks, W.; Bossler, A.D.; Lee, J.H. The PDZ Binding Motif of Human Papillomavirus Type 16 E6 Induces PTPN13 Loss, Which Allows Anchorage-Independent Growth and Synergizes with Ras for Invasive Growth. J. Virol. 2008, 82, 2493-2500. [CrossRef] [PubMed]

74. Xu, S.; Wang, T.; Yang, Z.; Li, Y.; Li, W.; Wang, T.; Wang, S.; Jia, L.; Zhang, S.; Li, S.-Q. miR-26a desensitizes non-small cell lung cancer cells to tyrosine kinase inhibitors by targeting PTPN13. Oncotarget 2016, 7, 45687-45701. [CrossRef] [PubMed]

75. Zhuang, L.; Shou, T.; Li, K.; Gao, C.; Duan, L.; Fang, L.; Zhang, Q.; Chen, Z.; Zhang, C.; Yang, S.; et al. MicroRNA-30e-5p promotes cell growth by targetingPTPN13and indicates poor survival and recurrence in lung adenocarcinoma. J. Cell. Mol. Med. 2017, 21, 2852-2862. [CrossRef]

76. Yu, M.; Maden, S.K.; Stachler, M.; Kaz, A.M.; Ayers, J.; Guo, Y.; Carter, K.T.; Willbanks, A.; Heinzerling, T.J.; O'Leary, R.M.; et al. Subtypes of Barrett's oesophagus and oesophageal adenocarcinoma based on genome-wide methylation analysis. Gut 2018, 68, 389-399. [CrossRef]

77. Yamada, A.; Inoue, E.; Deguchi-Tawarada, M.; Matsui, C.; Togawa, A.; Nakatani, T.; Ono, Y.; Takai, Y. Necl-2/CADM1 interacts with ErbB4 and regulates its activity in GABAergic neurons. Mol. Cell. Neurosci. 2013, 56, 234-243. [CrossRef]

78. Sugiyama, H.; Mizutani, K.; Kurita, S.; Okimoto, N.; Shimono, Y.; Takai, Y. Interaction of Necl-4/CADM4 with ErbB3 and integrin $\alpha 6 \beta 4$ and inhibition of ErbB2/ErbB3 signaling and hemidesmosome disassembly. Genes Cells 2013, 18, 519-528. [CrossRef]

79. Narisawa-Saito, M.; Kiyono, T. Basic mechanisms of high-risk human papillomavirus-induced carcinogenesis: Roles of E6 and E7 proteins. Cancer Sci. 2007, 98, 1505-1511. [CrossRef] 
80. Hausen, H.Z. Papillomaviruses and cancer: From basic studies to clinical application. Nat. Rev. Cancer 2002, 2, 342-350. [CrossRef]

81. Gardiol, D.; Kühne, C.; Glaunsinger, B.; Lee, S.S.; Javier, R.; Banks, L. Oncogenic human papillomavirus E6 proteins target the discs large tumour suppressor for proteasome-mediated degradation. Oncogene 1999, 18, 5487-5496. [CrossRef] [PubMed]

82. Doorbar, J.; Egawa, N.; Griffin, H.; Kranjec, C.; Murakami, I. Human papillomavirus molecular biology and disease association. Rev. Med. Virol. 2015, 25, 2-23. [CrossRef] [PubMed]

83. Hoover, A.C.; Spanos, W.C.; Harris, G.F.; Anderson, M.E.; Klingelhutz, A.J.; Lee, J.H. The Role of Human Papillomavirus 16 E6 in Anchorage-Independent and Invasive Growth of Mouse Tonsil Epithelium. Arch. Otolaryngol. Head Neck Surg. 2007, 133, 495-502. [CrossRef] [PubMed]

84. Wieking, B.G.; Vermeer, D.W.; Spanos, W.C.; Lee, K.M.; Vermeer, P.; Lee, W.T.; Xu, Y.; Gabitzsch, E.S.; Balcaitis, S.; Balint, J.P.; et al. A non-oncogenic HPV 16 E6/E7 vaccine enhances treatment of HPV expressing tumors. Cancer Gene Ther. 2012, 19, 667-674. [CrossRef]

85. Karin, M.; Ben-Neriah, Y. Phosphorylation Meets Ubiquitination: The Control of NF-kB Activity. Annu. Rev. Immunol. 2000, 18, 621-663. [CrossRef]

86. Viatour, P.; Merville, M.-P.; Bours, V.; Chariot, A. Phosphorylation of NF-kB and IкB proteins: Implications in cancer and inflammation. Trends Biochem. Sci. 2005, 30, 43-52. [CrossRef]

87. Schoonbroodt, S.; Ferreira, V.; Best-Belpomme, M.; Boelaert, J.R.; Legrand-Poels, S.; Korner, M.; Piette, J. Crucial Role of the Amino-Terminal Tyrosine Residue 42 and the Carboxyl-Terminal PEST Domain of IkB $\alpha$ in NF-kB Activation by an Oxidative Stress. J. Immunol. 2000, 164, 4292-4300. [CrossRef]

88. Fan, C.; Yang, J.; Engelhardt, J.F. Temporal pattern of NFKB activation influences apoptotic cell fate in a stimuli-dependent fashion. J. Cell Sci. 2002, 115, 4843-4853. [CrossRef]

89. Wang, Y.; Li, M.; Huang, T.; Li, J. Protein tyrosine phosphatase L1 inhibits high-grade serous ovarian carcinoma progression by targeting IкB $\alpha$. OncoTargets Ther. 2018, 11, 7603-7612. [CrossRef]

90. Zhan, H.; Jiang, J.; Luo, C.; Sun, Q.; Ke, A.; Sun, C.; Hu, J.; Hu, Z.; Hu, B.; Zhu, K.; et al. Tumour-suppressive role of PTPN13 in hepatocellular carcinoma and its clinical significance. Tumor Biol. 2016, 37, 9691-9698. [CrossRef]

91. Ranković, B.; Zidar, N.; Žlajpah, M.; Boštjančič, E. Epithelial-Mesenchymal Transition-Related MicroRNAs and Their Target Genes in Colorectal Cancerogenesis. J. Clin. Med. 2019, 8, 1603. [CrossRef] [PubMed]

92. Gou, H.; Liang, J.Q.; Zhang, L.; Chen, H.; Zhang, Y.; Li, R.; Wang, X.; Ji, J.; Tong, J.H.; To, K.-F.; et al. TTPAL Promotes Colorectal Tumorigenesis by Stabilizing TRIP6 to Activate Wnt/ $\beta$-Catenin Signaling. Cancer Res. 2019, 79, 3332-3346. [CrossRef] [PubMed]

93. Castilla, C.; Flores, M.L.; Conde, J.M.; Medina, R.; Torrubia, F.J.; Japón, M.A.; Sáez, C. Downregulation of protein tyrosine phosphatase PTPL1 alters cell cycle and upregulates invasion-related genes in prostate cancer cells. Clin. Exp. Metastasis 2012, 29, 349-358. [CrossRef] [PubMed]

94. Tan, B.; Yatim, S.M.J.; Peng, S.; Gunaratne, J.; Hunziker, W.; Ludwig, A. The Mammalian Crumbs Complex Defines a Distinct Polarity Domain Apical of Epithelial Tight Junctions. Curr. Biol. 2020, 30, 2791-2804. [CrossRef] [PubMed]

95. López-Ruano, G.; Prieto-Bermejo, R.; Ramos, T.L.; San-Segundo, L.; Sánchez-Abarca, L.I.; Sanchezguijo, F.M.; Pérez-Simón, J.A.; Sánchez-Yagüe, J.; Llanillo, M.; Hernández-Hernández, Á. PTPN13 and $\beta$-Catenin Regulate the Quiescence of Hematopoietic Stem Cells and Their Interaction with the Bone Marrow Niche. Stem Cell Rep. 2015, 5, 516-531. [CrossRef]

96. Kuchay, S.; Duan, S.; Schenkein, E.; Peschiaroli, A.; Saraf, A.; Florens, L.; Washburn, M.P.; Pagano, M. FBXL2- and PTPL1-mediated degradation of $\mathrm{p} 110$-free $\mathrm{p} 85 \beta$ regulatory subunit controls the PI(3)K signalling cascade. Nat. Cell Biol. 2013, 15, 472-480. [CrossRef]

97. Bompard, G.; Puech, C.; Prébois, C.; Vignon, F.; Freiss, G. Protein-tyrosine Phosphatase PTPL1/FAP-1 Triggers Apoptosis in Human Breast Cancer Cells. J. Biol. Chem. 2002, 277, 47861-47869. [CrossRef]

98. Freiss, G.; Puech, C.; Vignon, F. Extinction of Insulin-Like Growth Factor-I Mitogenic Signaling by Antiestrogen-Stimulated Fas-Associated Protein Tyrosine Phosphatase-1 in Human Breast Cancer Cells. Mol. Endocrinol. 1998, 12, 568-579. [CrossRef]

99. Long, Q.; Sun, J.; Lv, J.; Liang, Y.; Li, H.; Li, X. PTPN13 acts as a tumor suppressor in clear cell renal cell carcinoma by inactivating Akt signaling. Exp. Cell Res. 2020, 396, 112286. [CrossRef] 
100. Bruurs, L.J.M.; Van Der Net, M.C.; Zwakenberg, S.; Huber, A.K.M.R.; Post, A.; Zwartkruis, F.J.; Bos, J.L. The Phosphatase PTPL1 Is Required for PTEN-Mediated Regulation of Apical Membrane Size. Mol. Cell. Biol. 2018, 38, e00102-e00118. [CrossRef]

101. Han, X.-J.; Xue, L.; Gong, L.; Zhu, S.-J.; Yao, L.; Wang, S.-M.; Lan, M.; Zhang, W.; Li, Y.-H. Stat3 Inhibits PTPN13 Expression in Squamous Cell Lung Carcinoma through Recruitment of HDAC5. BioMed Res. Int. 2013, 2013, 1-7. [CrossRef] [PubMed]

102. Li, L.X.; Zhou, J.X.; Calvet, J.P.; Godwin, A.K.; Jensen, R.A.; Li, X. Lysine methyltransferase SMYD2 promotes triple negative breast cancer progression. Cell Death Dis. 2018, 9, 1-17. [CrossRef] [PubMed]

103. Li, L.X.; Fan, L.X.; Zhou, J.X.; Grantham, J.J.; Calvet, J.P.; Sage, J.; Li, X. Lysine methyltransferase SMYD2 promotes cyst growth in autosomal dominant polycystic kidney disease. J. Clin. Investig. 2017, 127, 2751-2764. [CrossRef] [PubMed]

104. Yan, Y.; Huang, P.; Mao, K.; He, C.; Xu, Q.; Zhang, M.; Liu, H.; Zhou, Z.; Zhou, Q.; Zhou, Q.; et al. Anti-oncogene PTPN13 inactivation by hepatitis B virus $X$ protein counteracts IGF2BP1 to promote hepatocellular carcinoma progression. Oncogene 2020, 1-18. [CrossRef]

105. Hao, S.X.; Ren, R.; Jahn, T.; Seipel, P.; Urschel, S.; Peschel, C.; Duyster, J. Expression of Interferon Consensus Sequence Binding Protein (ICSBP) Is Downregulated in Bcr-Abl-Induced Murine Chronic Myelogenous Leukemia-Like Disease, and Forced Coexpression of ICSBP Inhibits Bcr-Abl-Induced Myeloproliferative Disorder. Mol. Cell. Biol. 2000, 20, 1149-1161. [CrossRef] [PubMed]

106. Huang, W.; Zhu, C.; Wang, H.; Horvath, E.; Eklund, E.A. The Interferon Consensus Sequence-binding Protein (ICSBP/IRF8) RepressesPTPN13Gene Transcription in Differentiating Myeloid Cells. J. Biol. Chem. 2008, 283, 7921-7935. [CrossRef] [PubMed]

107. Huang, W.; Hu, L.; Bei, L.; Hjort, E.; Eklund, E.A. The Leukemia-associated Fusion Protein Tel-Platelet-derived Growth Factor Receptor $\beta$ (Tel-PdgfR $\beta$ ) Inhibits Transcriptional Repression ofPTPN13Gene by Interferon Consensus Sequence Binding Protein (Icsbp). J. Biol. Chem. 2012, 287, 8110-8125. [CrossRef]

108. Abaan, O.D.; Levenson, A.; Khan, O.; Furth, P.A.; Üren, A.; Toretsky, J.A. PTPL1 is a direct transcriptional target of EWS-FLI1 and modulates Ewing's Sarcoma tumorigenesis. Oncogene 2005, 24, 2715-2722. [CrossRef]

109. Kalyani, R.; Lee, J.Y.; Min, H.; Yoon, H.; Kim, M.H. Genes Frequently Coexpressed with Hoxc8 Provide Insight into the Discovery of Target Genes. Mol. Cells 2016, 39, 395-402. [CrossRef]

110. Ying, J.; Li, H.; Cui, Y.; Wong, A.H.Y.; Langford, C.; Tao, Q. Epigenetic disruption of two proapoptotic genes MAPK10/JNK3 and PTPN13/FAP-1 in multiple lymphomas and carcinomas through hypermethylation of a common bidirectional promoter. Leukemia 2006, 20, 1173-1175. [CrossRef]

111. Yeh, S.-H.; Wu, D.-C.; Tsai, C.-Y.; Kuo, T.-J.; Yuan-Shau, C.; Chang, Y.-S.; Chen, C.-L.; Chang, C.-F.; Chen, D.-S.; Chen, P.-J. Genetic Characterization of Fas-Associated Phosphatase-1 as a Putative Tumor Suppressor Gene on Chromosome 4q21.3 in Hepatocellular Carcinoma. Clin. Cancer Res. 2006, 12, 1097-1108. [CrossRef] [PubMed]

112. Wang, W.; Wang, J.; Li, M.; Ying, J.; Jing, H. 5-Azacitidine induces demethylation of PTPL1 and inhibits growth in non-Hodgkin lymphoma. Int. J. Mol. Med. 2015, 36, 698-704. [CrossRef] [PubMed]

113. Wang, W.; Wang, J.; Li, Z.; Zhu, M.; Zhang, Z.; Wang, Y.; Jing, H.-M. Promoter hypermethylation of PTPL1, PTPN6, DAPK, p16 and 5-azacitidine inhibits growth in DLBCL. Oncol. Rep. 2015, 35, 139-146. [CrossRef] [PubMed]

114. Mao, L.; Liu, S.; Hu, L.; Jia, L.; Wang, H.; Guo, M.; Chen, C.; Liu, Y.; Xu, L. miR-30 Family: A Promising Regulator in Development and Disease. BioMed Res. Int. 2018, 2018, 1-8. [CrossRef] [PubMed]

115. Wang, G.; Zhang, H.; He, H.; Tong, W.; Wang, B.; Liao, G.; Chen, Z.; Du, C. Up-regulation of microRNA in bladder tumor tissue is not common. Int. Urol. Nephrol. 2009, 42, 95-102. [CrossRef]

116. Daiuto, F.; Callari, M.; Dugo, M.; Merlino, G.; Musella, V.; Miodini, P.; Paolini, B.; Cappelletti, V.; Daidone, M.G. miR-30 $\mathrm{e}^{*}$ is an independent subtype-specific prognostic marker in breast cancer. Br. J. Cancer 2015, 113, 290-298. [CrossRef]

117. D’Angelo, E.; Fassan, M.; Maretto, I.; Pucciarelli, S.; Zanon, C.; Digito, M.; Rugge, M.; Nitti, D.; Agostini, M. Serum miR-125b is a non-invasive predictive biomarker of the pre-operative chemoradiotherapy responsiveness in patients with rectal adenocarcinoma. Oncotarget 2016, 7, 28647-28657. [CrossRef]

118. Cinpolat, O.; Unal, Z.N.; Ismi, O.; Gorur, A.; Unal, M. Comparison of microRNA profiles between benign and malignant salivary gland tumors in tissue, blood and saliva samples: A prospective, case-control study. Braz. J. Otorhinolaryngol. 2017, 83, 276-284. [CrossRef] 
119. Cinegaglia, N.C.; Andrade, S.C.S.; Tokar, T.; Pinheiro, M.; Severino, F.E.; Oliveira, R.A.; Hasimoto, E.N.; Cataneo, D.C.; Cataneo, A.J.M.; Defaveri, J.; et al. Integrative transcriptome analysis identifies deregulated microRNA-transcription factor networks in lung adenocarcinoma. Oncotarget 2016, 7, 28920-28934. [CrossRef]

120. Peter, M.E. Let-7 and miR-200 microRNAs: Guardians against pluripotency and cancer progression. Cell Cycle 2009, 8, 843-852. [CrossRef]

121. Liu, H.; Brannon, A.R.; Reddy, A.; Alexe, G.; Seiler, M.W.; Arreola, A.; Oza, J.H.; Yao, M.; Juan, D.; Liou, L.S.; et al. Identifying mRNA targets of microRNA dysregulated in cancer: With application to clear cell Renal Cell Carcinoma. BMC Syst. Biol. 2010, 4, 51. [CrossRef] [PubMed]

122. GeneCards PTPN13 Gene. Available online: https://www.genecards.org/cgi-bin/carddisp.pl?gene=PTPN13 (accessed on 11 December 2020).

123. Bowler, E.; Porazinski, S.; Uzor, S.; Thibault, P.; Durand, M.; Lapointe, E.; Rouschop, K.M.A.; Hancock, J.; Wilson, I.; Ladomery, M. Hypoxia leads to significant changes in alternative splicing and elevated expression of CLK splice factor kinases in PC3 prostate cancer cells. BMC Cancer 2018, 18, 1-11. [CrossRef] [PubMed]

124. Meinhold-Heerlein, I.; Stenner-Liewen, F.; Liewen, H.; Kitada, S.; Krajewska, M.; Krajewski, S.; Zapata, J.M.; Monks, A.; Scudiero, D.A.; Bauknecht, T.; et al. Expression and Potential Role of Fas-Associated Phosphatase-1 in Ovarian Cancer. Am. J. Pathol. 2001, 158, 1335-1344. [CrossRef]

125. D’Hondt, V.; Lacroix-Triki, M.; Jarlier, M.; Boissiere-Michot, F.; Puech, C.; Coopman, P.; Katsaros, D.; Freiss, G. High PTPN13 expression in high grade serous ovarian carcinoma is associated with a better patient outcome. Oncotarget 2017, 8, 95662-95673. [CrossRef] [PubMed]

126. Révillion, F.; Puech, C.; Rabenoelina, F.; Chalbos, D.; Peyrat, J.-P.; Freiss, G. Expression of the putative tumor suppressor genePTPN13/PTPL1is an independent prognostic marker for overall survival in breast cancer. Int. J. Cancer 2009, 124, 638-643. [CrossRef] [PubMed]

127. Han, X.; Xue, L.; Zhou, L.; Gong, L.; Zhu, S.; Yao, L.; Wang, S.; Lan, M.; Li, Y.-H.; Zhang, W. The role of PTPN13 in invasion and metastasis of lung squamous cell carcinoma. Exp. Mol. Pathol. 2013, 95, 270-275. [CrossRef] [PubMed]

128. Sun, Z.; Wang, L.; Eckloff, B.W.; Deng, B.; Wang, Y.; Wampfler, J.; Jang, J.S.; Wieben, E.D.; Jen, J.; You, M.; et al. Conserved recurrent gene mutations correlate with pathway deregulation and clinical outcomes of lung adenocarcinoma in never-smokers. BMC Med. Genom. 2014, 7, 486. [CrossRef]

129. Borinstein, S.C.; Barkauskas, N.A.; Krailo, M.; Scher, D.; Scher, L.; Schlottmann, S.; Kallakury, B.; Dickman, P.S.; Pawel, B.R.; West, D.C.; et al. Investigation of the insulin-like growth factor-1 signaling pathway in localized Ewing sarcoma: A report from the Children's Oncology Group. Cancer 2011, 117, 4966-4976. [CrossRef]

130. Foehr, E.D.; Lorente, G.; Vincent, V.; Nikolich, K.; Urfer, R. FAS Associated Phosphatase (FAP-1) Blocks Apoptosis of Astrocytomas through Dephosphorylation of FAS. J. Neuro Oncol. 2005, 74, 241-248. [CrossRef]

131. O'Connell, J.; Bennett, M.W.; O'Sullivan, G.C.; Roche, D.; Kelly, J.; Collins, J.K.; Shanahan, F. Fas ligand expression in primary colon adenocarcinomas: Evidence that the Fas counterattack is a prevalent mechanism of immune evasion in human colon cancer. J. Pathol. 1998, 186, 240-246. [CrossRef]

132. Colbert, P.L.; Vermeer, D.W.; Wieking, B.G.; Lee, J.H.; Vermeer, P.D. EphrinB1: Novel microtubule associated protein whose expression affects taxane sensitivity. Oncotarget 2014, 6, 953-968. [CrossRef] [PubMed]

133. Wang, L.; Gan, Y. Cancer-derived IgG involved in cisplatin resistance through PTP-BAS/Src/PDK1/AKT signaling pathway. Oral Dis. 2020. [CrossRef] [PubMed]

134. Wrage, M.; Ruosaari, S.; Eijk, P.P.; Kaifi, J.T.; Hollmén, J.; Yekebas, E.F.; Izbicki, J.R.; Brakenhoff, R.H.; Streichert, T.; Riethdorf, S.; et al. Genomic Profiles Associated with Early Micrometastasis in Lung Cancer: Relevance of 4q Deletion. Clin. Cancer Res. 2009, 15, 1566-1574. [CrossRef] [PubMed]

135. Gorringe, K.L.; Ramakrishna, M.; Williams, L.H.; Sridhar, A.; Boyle, S.E.; Bearfoot, J.L.; Li, J.; Anglesio, M.S.; Campbell, I.G. Are there any more ovarian tumor suppressor genes? A new perspective using ultra high-resolution copy number and loss of heterozygosity analysis. Genes Chromosom. Cancer 2009, 48, 931-942. [CrossRef] [PubMed]

136. Schneider, J.A.; Pungliya, M.S.; Choi, J.Y.; Jiang, R.; Sun, X.J.; Salisbury, B.A.; Stephens, J.C. DNA variability of human genes. Mech. Ageing Dev. 2003, 124, 17-25. [CrossRef]

137. Mita, Y.; Yasuda, Y.; Sakai, A.; Yamamoto, H.; Toyooka, S.; Gunduz, M.; Tanabe, S.; Naomoto, Y.; Ouchida, M.; Shimizu, K. Missense polymorphisms of PTPRJ and PTPN13 genes affect susceptibility to a variety of human cancers. J. Cancer Res. Clin. Oncol. 2009, 136, 249-259. [CrossRef] [PubMed] 
138. Laczmanska, I.; Karpiński, P.; Gil, J.; Laczmanski, L.; Makowska, I.; Bebenek, M.; Ramsey, D.; Sąsiadek, M.M. ThePTPN13Y2081D (T>G) (rs989902) polymorphism is associated with an increased risk of sporadic colorectal cancer. Color. Dis. 2017, 19, O272-O278. [CrossRef] [PubMed]

139. Niu, J.; Huang, Y.-J.; Wang, L.-E.; Sturgis, E.M.; Wei, P. Genetic polymorphisms in the PTPN13 gene and risk of squamous cell carcinoma of head and neck. Carcinogenesis 2009, 30, 2053-2058. [CrossRef]

140. Wei, W.; Jiang, M.; Luo, L.; Li, Z.; Wang, P.; Dong, W. Colorectal cancer susceptibility variants alter risk of breast cancer in a Chinese Han population. Genet. Mol. Res. 2013, 12, 6268-6274. [CrossRef] [PubMed]

141. Lim, B.; Kim, C.; Kim, J.-H.; Kwon, W.S.; Lee, W.S.; Park, J.Y.; Kim, H.S.; Park, K.H.; Kim, T.S.; Park, J.-L.; et al. Genetic alterations and their clinical implications in gastric cancer peritoneal carcinomatosis revealed by whole-exome sequencing of malignant ascites. Oncotarget 2016, 7, 8055-8066. [CrossRef]

142. Musolf, A.M.; Moiz, B.A.; Sun, H.; Pikielny, C.W.; Bossé, Y.; Mandal, D.; De Andrade, M.; Gaba, C.; Yang, P.; Li, Y.; et al. Whole Exome Sequencing of Highly Aggregated Lung Cancer Families Reveals Linked Loci for Increased Cancer Risk on Chromosomes 12q, 7p, and 4q. Cancer Epidemiol. Biomark. Prev. 2020, 29, 434-442. [CrossRef]

143. Jeong, E.G.; Lee, S.H.; Yoo, N.J.; Lee, S.H. Mutational analysis of FLASH and PTPN13 genes in colorectal carcinomas. Pathology 2008, 40, 31-34. [CrossRef] [PubMed]

144. Hoover, A.C.; Strand, G.L.; Nowicki, P.N.; Anderson, M.E.; Vermeer, P.D.; Klingelhutz, A.J.; Bossler, A.D.; Pottala, J.V.; Hendriks, W.J.A.J.; Lee, J.H. Impaired PTPN13 phosphatase activity in spontaneous or HPV-induced squamous cell carcinomas potentiates oncogene signaling through the MAP kinase pathway. Oncogene 2009, 28, 3960-3970. [CrossRef] [PubMed]

145. Wang, Z.; Shen, D.; Parsons, D.W.; Bardelli, A.; Sager, J.; Szabo, S.; Ptak, J.; Silliman, N.; Peters, B.A.; Van Der Heijden, M.S.; et al. Mutational Analysis of the Tyrosine Phosphatome in Colorectal Cancers. Science 2004, 304, 1164-1166. [CrossRef] [PubMed]

146. Yu, D.; Son, W.; Lim, J.; Xiao, G. Statistical completion of a partially identified graph with applications for the estimation of gene regulatory networks. Biostatistics 2015, 16, 670-685. [CrossRef] [PubMed]

147. Baudry, M. Calpain-1 and Calpain-2 in the Brain: Dr. Jekill and Mr Hyde? Curr. Neuropharmacol. 2019, 17, 823-829. [CrossRef]

Publisher's Note: MDPI stays neutral with regard to jurisdictional claims in published maps and institutional affiliations.

(C) 2020 by the authors. Licensee MDPI, Basel, Switzerland. This article is an open access article distributed under the terms and conditions of the Creative Commons Attribution (CC BY) license (http://creativecommons.org/licenses/by/4.0/). 